\title{
Recent Advancements in the Development of Anti-Breast Cancer Synthetic Small Molecules
}

\author{
Eslam B. Elkaeed ${ }^{1}\left(\mathbb{D}\right.$, Hayam A. Abd El Salam ${ }^{2}$, Ahmed Sabt ${ }^{3} \mathbb{D}$, Ghada H. Al-Ansary ${ }^{4}$ and Wagdy M. Eldehna ${ }^{5, * \mathbb{D}}$ \\ 1 Department of Pharmaceutical Sciences, College of Pharmacy, AlMaarefa University, Ad Diriyah, \\ Riyadh 13713, Saudi Arabia; ikaeed@mcst.edu.sa \\ 2 Department of Green Chemistry, National Research Center, Dokki, Cairo 12622, Egypt; \\ hayam_nrc@yahoo.com \\ 3 Chemistry of Natural Compounds Department, National Research Center, Dokki, Cairo 12622, Egypt; \\ sabt.nrc@gmail.com \\ 4 Department of Pharmaceutical Chemistry, Faculty of Pharmacy, Ain Shams University, Cairo 11566, Egypt; \\ ghada.mohamed@pharma.asu.edu.eg \\ 5 Department of Pharmaceutical Chemistry, Faculty of Pharmacy, Kafrelsheikh University, \\ Kafrelsheikh 33516, Egypt \\ * Correspondence: wagdy2000@gmail.com
}

check for updates

Citation: Elkaeed, E.B.; Salam, H.A.A.E.; Sabt, A.; Al-Ansary, G.H.; Eldehna, W.M. Recent Advancements in the Development of Anti-Breast Cancer Synthetic Small Molecules. Molecules 2021, 26, 7611. https:// doi.org/10.3390/molecules26247611

Academic Editor: Belgin Sever

Received: 18 October 2021

Accepted: 10 December 2021

Published: 15 December 2021

Publisher's Note: MDPI stays neutral with regard to jurisdictional claims in published maps and institutional affiliations.

Copyright: (c) 2021 by the authors. Licensee MDPI, Basel, Switzerland. This article is an open access article distributed under the terms and conditions of the Creative Commons Attribution (CC BY) license (https:/ / creativecommons.org/licenses/by/ $4.0 /)$.

\begin{abstract}
Among all cancer types, breast cancer (BC) still stands as one of the most serious diseases responsible for a large number of cancer-associated deaths among women worldwide, and diagnosed cases are increasing year by year worldwide. For a very long time, hormonal therapy, surgery, chemotherapy, and radiotherapy were used for breast cancer treatment. However, these treatment approaches are becoming progressively futile because of multidrug resistance and serious side effects. Consequently, there is a pressing demand to develop more efficient and safer agents that can fight breast cancer belligerence and inhibit cancer cell proliferation, invasion and metastasis. Currently, there is an avalanche of newly designed and synthesized molecular entities targeting multiple types of breast cancer. This review highlights several important synthesized compounds with promising anti-BC activity that are categorized according to their chemical structures.
\end{abstract}

Keywords: breast cancer therapy; organic synthesis; chemical scaffold; mechanistic insights; human malignancies

\section{Introduction}

Worldwide, breast cancer is the most prevalent cancer and the second type of cancer leading to mortality in women [1]. More than 276,480 new breast cancer cases are expected to be identified in women in the United States in 2020 [2]. Risk factors linked to breast cancer continue to be identified [3]. Accordingly, breast cancer is considered one of the urgent public health problems globally [4].

Breast cancer is promoted via different types of factors (endogenous and exogenous) which have differing outcomes [5]. Treatment of invasive $\mathrm{BC}$ is quite challenging due to its aggressive features [6,7]. A plentiful body of evidence suggests that long-term survival can be increased, if there is an ability to suppress distant metastasis [8,9]. Breast cancer treatment depends on a mechanism(s) that can be targeted by natural or synthetic compounds that already exist as antitumor drugs $[10,11]$. Not surprisingly, literature reviews revealed that many heterocyclic and/or other scaffolds have been developed as anti-breast cancer agents [12-14].

\section{Different Subtypes of Breast Cancer}

There are four main subtypes of female breast cancer [15] (Figure 1):

Luminal A: This group has tumors that are estrogen-receptor and/or progesterone-receptor positive (+ve ER and/or +ve PR), but it is human epidermal growth factor receptor negative 
(-ve HER2). In addition, this type possesses protein Ki-67 in low levels, which is beneficial to control the growth of cancer cells. This type generally has the best prognosis with low grade and grows slowly.

Luminal B: This group has tumors that are positive for ER and HER2 but negative for PR and possesses protein Ki-67 in high levels. Luminal B BCs mainly grow faster than luminal A BCs, and their prognosis is slightly worse. HER2-enriched (HR-/HER2+): This group has tumors that are negative ER, PR and positive for HER2. It is treated with targeted therapy to target the HER2 protein although it grows faster than luminal cancers with a worse prognosis. Examples of targeted therapies include Pertuzumab, Trastuzumab Deruxtecan, Trastuzumab Emtansine, Lapatinib, Trastuzumab, and Neratinib. Basal-like: This group is also named triple-negative breast cancer; it is negative for ER, PR and HER2. Unfortunately, it is the most common type with women with the gene mutation of BRCA1 among young and African-American women, and it is characterized by the missing signature of three biomarkers (PR, ER, HER2 proteins). Accordingly, it is the most aggressive type of BC.
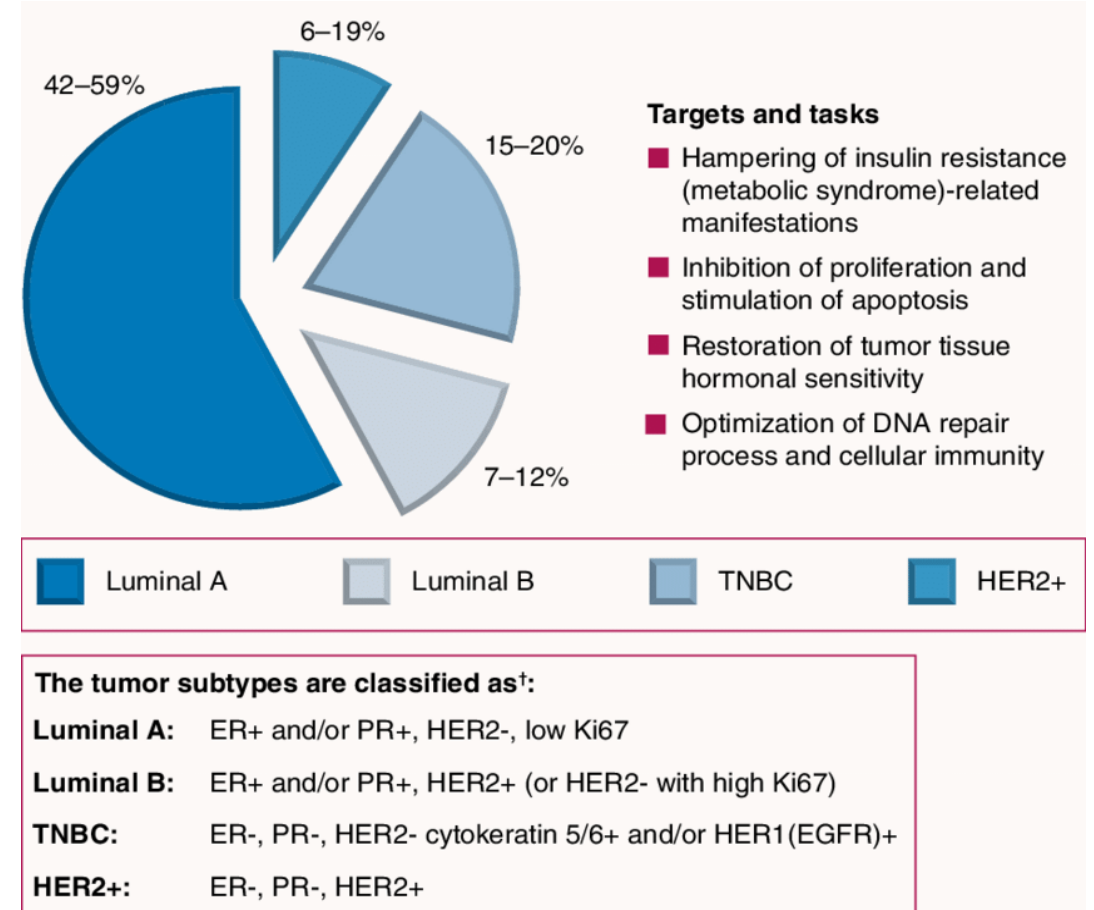

Figure 1. Representation for different breast cancer subtypes.

There are six subtypes of basal-like breast cancer reported by Lehmann et al. [16] which are treated differently [17]: basal-like 1 (BL1), basal-like 2 (BL2), Immunomodulatory (IM), Mesenchymal (M), Mesenchymal stem like (MSL), Luminal androgen receptor (LAR).

The BC subtype HR+/HER2 - (HR+ stands for BC cells possessing receptors for the hormones estrogen or progesterone) has been identified as the most common subtype with a rate of 85.8 new cases per 100,000 women, according to $2012-2016$ cases. This is a rate more than 6-fold higher than the TNBC rate of 13.0 and the HR+/HER2+ BC rate of 12.9, and over 15-fold higher than HR-/HER2+ BC rate of 5.4.

\section{Conventional Treatment and Its Drawbacks}

Management of breast cancer involves many treatment approaches that comprise chemotherapy, radiotherapy, surgery, and hormonal therapy [18]. Early stages of breast cancer, I and II, can be effectively treated by radiotherapy and chemotherapy, sparing the breast tissue [19]. These stages are accompanied by multiple forms of diseases such as 
pericarditis, rib fracture, tissue necrosis, brachial plexopathy, in addition to the second non-breast malignancies [20].

Multidrug resistance stands as a stubborn obstacle for management of BC which ultimately leads to death. Accordingly, the urgency arises for the thorough understanding and analysis of the cancer molecular basis of resistance and tailoring new drugs that target it effectively [21].

The emergence of resistance is caused by different mechanisms. Modulation of the drug efflux membrane transporter is the primary culprit for such resistance; these include P-glycoprotein, MRP 1, and BCRP [22,23]. This is evidenced by the observed patients immunity to several previously effective antineoplastic agents such as anthracyclines (epirubicin, daunorubicin, doxorubicin and mitoxantrone), taxanes (docetaxel, paclitaxel), and capecitabine [24]. Furthermore, the practice of using mono therapy in the treatment of breast cancer gave a remarkable capacity to start flooding the tumor mass with a growing supply of new cancer cells [25]. Moreover, the reduction in white blood cells and red blood cells as major side effects for chemotherapy led to increasing the risk of infection and anemia with decreased $\mathrm{O}_{2}$ carrying capacity for the cells, respectively [26]. Accordingly, seeking an alternative approach for the management of $\mathrm{BC}$ on the basis of all these understandings is an urgent necessity which could prevent and minimize the risk of unexpected side effects of conventional treatment methods [27].

\section{Recent Drugs Approved for Breast Cancer Management}

Many drugs are approved by the FDA for various BC subtypes therapy, and are described in the following sections.

\subsection{Eribulin}

Eribulin (Figure 2) is a synthetic ketone analog of the macrocyclic chemotherapeutically active halichondrin B derived from the sea sponge Halichondria okadai. Eribulin is a potent mitotic inhibitor with a unique mechanism of action as an inhibitor of microtubule dynamics. Eribulin received its FDA approval in 2010 to manage the metastatic breast cancer in patients who have received at least two prior chemotherapy regimens for late-stage disease [28].

\subsection{Everolimus}

Everolimus (Figure 2), a derivative of the natural macrocyclic lactone sirolimus, is an orally bioavailable inhibitor of mTOR. On 20 July 2012, the U.S. FDA approved Everolimus for the treatment of post-menopausal women with advanced HR+/HER2 - breast cancer. It is worth mentioning that Everolimus has been approved also for tuberous sclerosis complexassociated partial-onset seizures (in 2018), progressive, nonfunctional gastrointestinal and lung neuroendocrine tumors (in 2016), and advanced pancreatic neuroendocrine tumors (in 2011), as well as being the first approved pediatric-specific dosage form for the management of a rare pediatric brain tumor called subependymal giant cell astrocytoma [29-31].

\subsection{Neratinib}

Neratinib (Figure 2), a 4-anilinoquinoline-based orally bioavailable kinase inhibitor, is an irreversible pan-ErbB inhibitor of EGFR, HER2, and HER4 targeting the intracellular domain, which results in reduced phosphorylation and downstream pathways activation. Neratinib has been recently FDA- and EMA-approved for the extended adjuvant treatment of early stage HER2-positive BC [32].

\subsection{Palbociclib}

Palbociclib (Figure 2) is a pyrido[2,3- $d$ ]pyrimidin-7-one derivative which acts as a selective CDK4/ 6 inhibitor. On 3 February 2015, the FDA granted accelerated approval of Palbociclib (in combination with letrozole) for postmenopausal women with advanced breast 
cancer, then in 2016 Palbociclib was approved for treatment of HR+/HER2 - metastatic BC. Notably, Palbociclib was the first-in-class CDK $4 / 6$ inhibitor approved by the FDA [33].

\subsection{Ribociclib}

Ribociclib (Figure 2) is a pyrrolo[2,3-d]pyrimidine-based potent selective inhibitor of cyclin-dependent kinases (CDKs) 4 and 6. In 2017, the FDA approved Ribociclib for treatment of patients with HR+/HER2 - metastatic BC. One year later, it was additionally approved for HR+/HER2 - advanced breast cancer [34].

\subsection{Tucatinib}

Tucatinib (Figure 2) is an orally bioavailable HER2 tyrosine kinase inhibitor. On 17 April 2020, the FDA granted an approval for tucatinib, in combination with Trastuzumab and capecitabine, for the management of patients with advanced unresectable or metastatic HER2-positive BC [35].
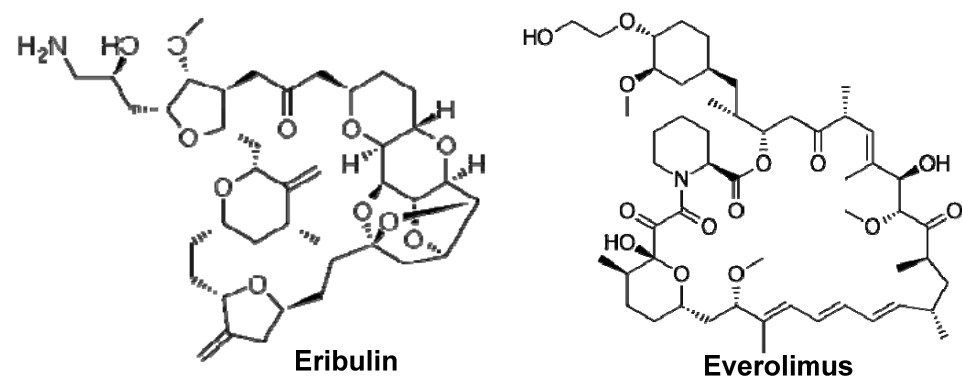<smiles>CCOc1cc2ncc(C#N)c(Nc3ccc(OCc4ccccn4)c(Cl)c3)c2cc1NC(=O)/C=C/CN(C)C</smiles><smiles>CC(=O)c1c(C)c2cnc(Nc3ccc(N4CCNCC4)cn3)nc2n(C2CCCC2)c1=O</smiles><smiles>CN(C)C(=O)c1cc2cnc(Nc3ccc(N4CCNCC4)cn3)nc2n1C1CCCC1</smiles><smiles>Cc1cc(Nc2ncnc3ccc(NC4=NC(C)(C)CO4)cc23)ccc1Oc1ccn2ncnc2c1</smiles>

Tucatinib<smiles>CC(C)(C#N)c1cc(Cn2cncn2)cc(C(C)(C)C#N)c1</smiles>

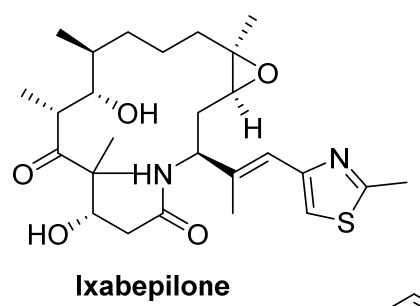

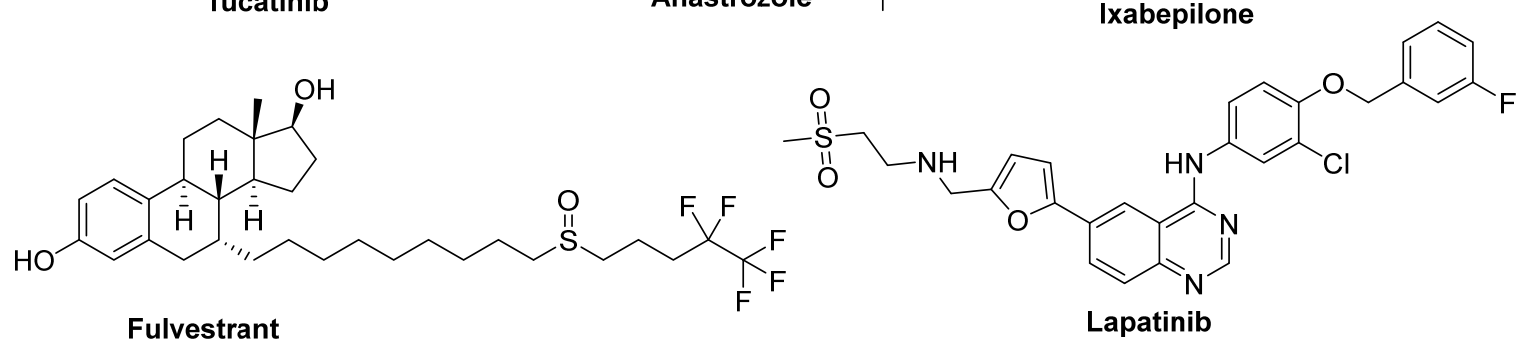<smiles>Cc1nc(NC(=O)N2CCCC2C(N)=O)sc1-c1ccnc(C(C)(C)C(F)(F)F)c1</smiles><smiles>Cn1ncnc1C1c2n[nH]c(=O)c3cc(F)cc(c23)N[C@H]1c1ccc(F)cc1</smiles>

Figure 2. FDA-approved drugs for the management of different human breast malignancies. 


\subsection{Anastrozole}

Anastrozole (Figure 2) is a reversible, nonsteroidal inhibitor of the aromatase enzyme that is taken orally. Anastrozole is an essential anticancer drug that is indicated as an adjuvant remedy in the treatment of $\mathrm{HR}+\mathrm{BC}$ in postmenopausal women at early stages [36].

\subsection{Ixabepilone}

Ixabepilone (Figure 2), a semisynthetic analog of epothilone B, stabilizes the microtubules which are essential for cell division via suppression of the dynamic of microtubules $(\mathrm{a} \beta-\mathrm{II}$ and $\mathrm{a} \beta-\mathrm{II})$. Hence, it arrests the cell cycle in the G2-M phase, induces tumor cell apoptosis and inhibits tumor cell proliferation. In 2007, Ixabepilone was granted an FDA approval for the treatment of patients with locally advanced or aggressive metastatic BC [37].

\subsection{Fulvestrant}

Fulvestrant (Figure 2) is a synthetic estrogen receptor and an aromatase inhibitor. It decreases the amount of estrogen in the $\mathrm{BC}$ cells through binding to estrogen receptors which leads to estrogen receptor deformation [38].

\subsection{Lapatinib Oral-Active}

Lapatinib (Figure 2), a synthetic quinazoline derivative, is an orally active reversible ErbB1 and ErbB2 tyrosine kinase receptor inhibitor that possesses antineoplastic activity towards breast cancer [39].

\subsection{Pertuzumab}

Pertuzumab is a recombinant humanized monoclonal antibody that targets HER2positive $\mathrm{BC}$ which can inhibit the proliferation of human tumor cells [30]. The most common side effects of Pertuzumab include hair loss, low white blood cell count, rash, diarrhea, fatigue, nausea, and peripheral neuropathy (tingling in hands and feet and numbness) [40].

\subsection{Alpelisib}

Alpelisib (Figure 2) is a phosphatidylinositol 3-kinase (PI3K) inhibitor that impedes the growth of tumor cells. Alpelisib is used in combination with fulvestrant (Faslodex ${ }^{\circledR}$ ) for treatment of postmenopausal women with a certain type of metastatic BC [41].

\subsection{Talazoparib}

Talazoparib (Talzenna ${ }^{\circledR}$, Figure 2) belongs to a class of drugs called PARP inhibitors used for treatment of local advanced or metastatic HER2-negative BC women with a BRCA1 or BRCA2 mutation [42].

\section{Recently Developed Synthetic Anti-Breast Cancer Small Molecules}

\subsection{Quinoline-Based Small Molecules}

The great advances in the azaheterocyclic synthesis in the last decades allowed the synthesis of different quinoline derivatives. Recently, Viswas et al. reported the synthesis of two new sets of piperazinyl-quinoline derivatives bearing urea or thiourea functionalities based on the reaction of 4-(piperazin-1-yl)quinoline $3 \mathbf{a}-\mathbf{b}$ with isocyanate or thiocyanate derivatives. The synthesized quinolines were screened for their anti-proliferative activity against $\mathrm{BC}$ cell lines. The results highlighted that quinoline derivative 4 (Figure 3) possessed potent activity against MDA-MB-231 $\left(\mathrm{GI}_{50}=3.0 \pm 0.1 \mu \mathrm{M}\right)$, while quinoline derivative 5 (Figure 3) exhibited improved anti-proliferative impact towards MDA-MB468 and MCF-7 $\left(\mathrm{GI}_{50}=2.7 \pm 0.1\right.$ and $2.0 \pm 0.1 \mu \mathrm{M}$, respectively) [43]. 


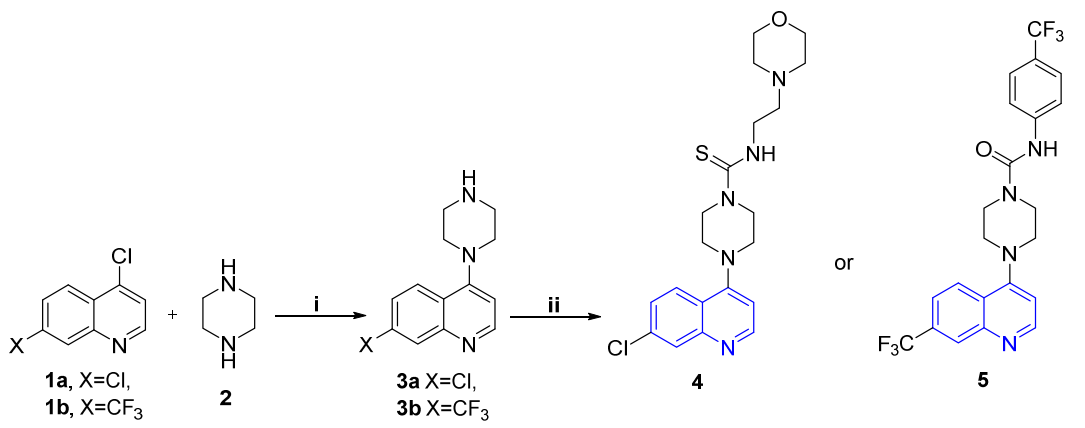

(i) $80^{\circ} \mathrm{C}$ for $1 \mathrm{~h}, 120-130^{\circ} \mathrm{C}$ for $6-8 \mathrm{~h}$;

(ii) RNCO or RNCS, DMF, rt, 4 hr.
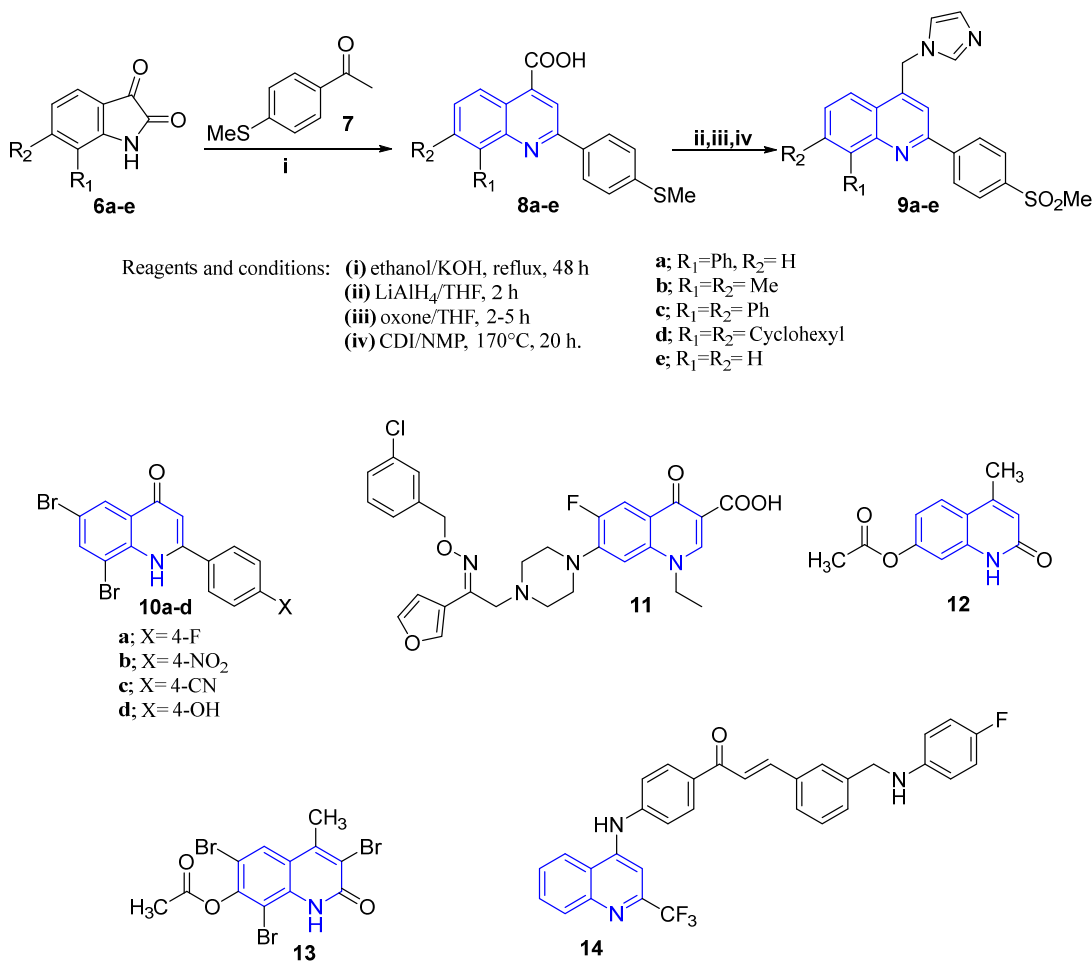

Figure 3. Quinoline-based small molecules as anti-breast cancer agents.

Previously, Zaghri et al. developed novel 4-(imidazolylmethyl)quinoline derivatives 9a-e (Figure 3) that proved to be useful as anti-BC agents against MCF-7 cells; moreover, they exhibited selective cyclooxygenase-2 (COX-2) inhibitory activity. Among the aforementioned compounds, the results revealed that compound $\mathbf{9 e}$ emerged as the most effective counterpart [44], (Figure 3).

Moreover, Bheemanapalli et al. [45] described the synthesis and anticancer activity evaluation of a new set of dihydroquinoline derivatives $\mathbf{1 0}$ and $\mathbf{1 1}$ (Figure 3). Preliminary screening revealed that compounds $10 a-d$ demonstrated potent growth inhibitory potential against breast cancer MCF-7 cell line compared to the reference drug. In addition, compound 11 (Figure 3) showed a significant growth inhibitory potential against three breast cancer cell lines: T47D, MCF-7 and MDA-MB-231, with $\mathrm{IC}_{50}$ values equal $2.20 \pm 1.5$, $3.03 \pm 1.5$ and $11.90 \pm 2.6 \mu \mathrm{M}$, respectively [46].

Moustafa et al. [47] synthesized a novel series of 2-quinolinone derivatives and evaluated their anti-proliferative activity against the BC MCF-7 cell line. The results revealed that compounds 12 and 13 (Figure 3) elicited the highest anti-proliferative activity. Moreover, these compounds cause induction of apoptosis at pre-G1 phase, beside cell cycle arrest $(\mathrm{G} 2 / \mathrm{M})$ phases. 
Most recently, Patel et al. [48] identified a novel class of 3-phenyltrifluoromethyl quinoline derivatives (Figure 3) and determined their anti-proliferative potential toward the breast cancer MCF-7 cell line. Among the synthesized derivatives, compound 14 displayed the highest anticancer activity with growth inhibition value in the nanomolar range $\left(\mathrm{GI}_{50}=4 \mathrm{nM}\right)$. The performed molecular docking analysis in this study suggests thymidine phosphorylase as a plausible target for the prepared 3-phenyltrifluoromethyl quinolines [48].

\subsection{Quinazoline- and Quinazolinone-Based Small Molecules}

Several quinazoline and quinazolinone derivatives have been synthesized and reported for their anti-breast cancer activity. In 2016, Yin et al. reported the design and synthesis of a novel set of oxazolo-quinazoline derivatives (Figure 4) as dual inhibitors of EGFR/HER2. Among the synthesized compounds, 18-21 revealed significant inhibition for EGFR and HER2. Furthermore, compound 21 showed excellent anti-proliferation activity against the SKBr-3 cell line with $\mathrm{IC}_{50}=0.47 \pm 0.35 \mu \mathrm{M}$, compared to the reference drug Lapatinib (Table 1, Figure 4) [49].

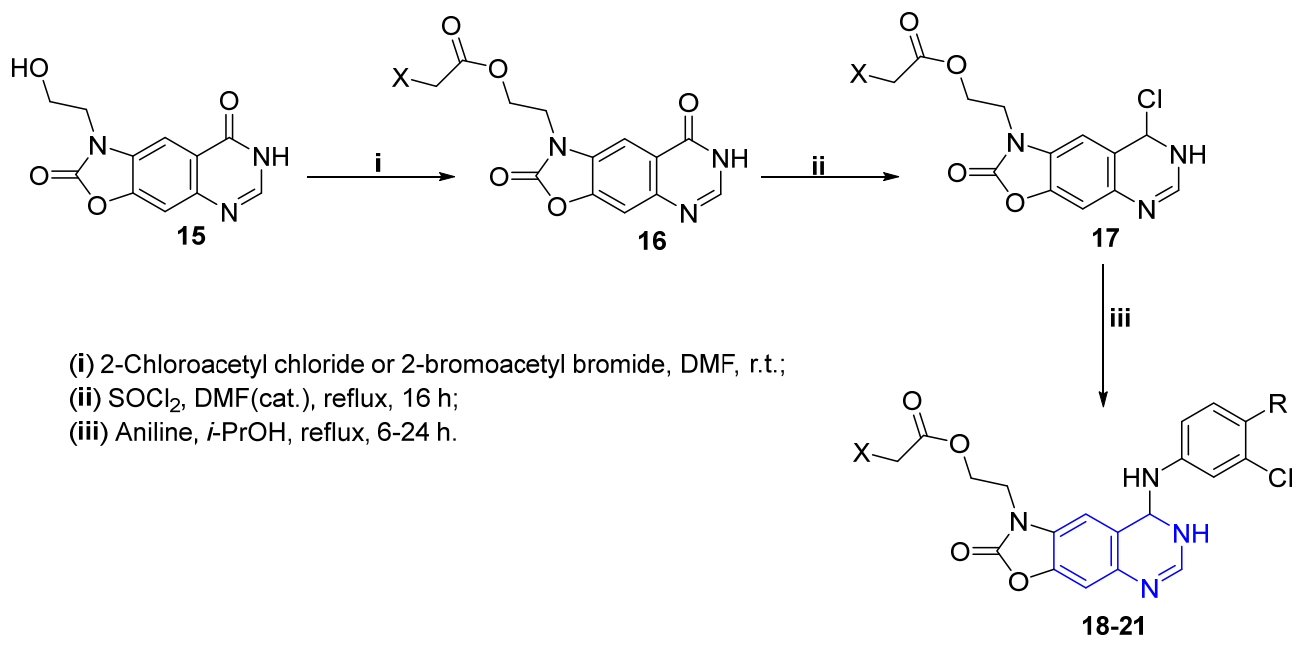

18; $\mathrm{X}=\mathrm{Br}, \mathrm{R}=4$-methylpiperazine

19; $\mathrm{X}=\mathrm{Br}, \mathrm{R}=$ morpholine

20; $\mathrm{X}=\mathrm{Cl}, \mathrm{R}=4$-methylpiperazine

21; $\mathrm{X}=\mathrm{Cl}, \mathrm{R}=$ morpholine<smiles>O=C(NN1C(=O)CSC1c1ccccc1)c1ccc(-n2c(-c3ccc(Cl)cc3)nc3c(Br)cc(Br)cc3c2=O)cc1</smiles><smiles>CC(=O)c1ccc(-n2c(-c3ccc(Cl)cc3)nc3c(Br)cc(Br)cc3c2=O)cc1</smiles><smiles>CC1CCCCN1Cn1c(-c2ccc(Cl)cc2)nc2c(Br)cc(Br)cc2c1=O</smiles><smiles>O=c1c2ccccc2nc(-c2cc(Br)ccc2O)n1/N=C/c1cc(Br)ccc1O</smiles><smiles>COc1cc(Br)cc(/C=N/n2c(-c3cc(Br)cc(OC)c3O)nc3ccccc3c2=O)c1O</smiles><smiles></smiles>

Figure 4. Quinazoline/quinazolinone derivatives as anti-breast cancer agents. 
Table 1. Inhibition activities of quinazolines 18-21 against EGFR and HER-2 kinases, as well as against A549 and SK-Br3 breast cancer cell lines.

\begin{tabular}{ccccc}
\hline \multirow{2}{*}{ Comp. } & \multicolumn{2}{c}{$\begin{array}{c}\text { Enzyme Inhibition } \\
\text { IC }_{\mathbf{5 0}}(\mathbf{n M})\end{array}$} & \multicolumn{2}{c}{$\begin{array}{c}\text { Cell Growth Inhibition } \\
\text { IC }_{\mathbf{5 0}}(\boldsymbol{\mu M})\end{array}$} \\
\cline { 2 - 5 } & EGFR & HER2 & A549 & SK-Br3 \\
\hline $\mathbf{1 8}$ & $8 \pm 0.4$ & $33 \pm 0.10$ & $2.03 \pm 0.54$ & $12.50 \pm 2.41$ \\
\hline $\mathbf{1 9}$ & $10 \pm 0.2$ & $21 \pm 0.7$ & $3.60 \pm 0.89$ & $2.30 \pm 0.37$ \\
\hline $\mathbf{2 0}$ & $20 \pm 0.11$ & $9 \pm 0.10$ & $1.22 \pm 0.60$ & $25.1 \pm 8.54$ \\
\hline $\mathbf{2 1}$ & $19 \pm 0.10$ & $35 \pm 0.8$ & $4.49 \pm 2.68$ & $0.47 \pm 0.35$ \\
\hline Lapatinib & $26 \pm 0.12$ & $17 \pm 0.10$ & $6.74 \pm 1.33$ & $0.49 \pm 0.04$ \\
\hline
\end{tabular}

Additionally, Ahmed et al. [50] discovered a new series of quinazolin-4-one derivatives and screened them against EGFR tyrosine kinase, as well as against the MCF-7 cell line. Compound 22 (Figure 4) revealed good EGFR inhibitory activity and powerful cytotoxic activity toward the tested MCF-7 cell line.

Furthermore, another novel series of quinazolin-4 $(3 H)$-one derivatives were designed, prepared and evaluated as anti-breast cancer agents [51], where compounds $\mathbf{2 3}$ and $\mathbf{2 4}$ (Figure 4) showed the highest activity against the MCF-7 cell line. Moreover, two new synthetic ellipticine analogs $\mathbf{2 5}$ and $\mathbf{2 6}$ (Figure 4) were designed and synthesized. Both compounds showed an elegant anti-proliferative effect for the MCF-7 cell line, with $\mathrm{IC}_{50}$ equal to $6.246 \mu \mathrm{mol} / \mathrm{L}$ and $5.910 \mu \mathrm{mol} / \mathrm{L}$, respectively. Additionally, the two molecules were proven to induce intrinsic and extrinsic apoptosis at the cellular level [52].

Recently, Wang et al. developed a new 4-aminoquinazoline derivative 27 (Figure 4), and verified that it suppressed the proliferation, growth, migration, and invasion of human breast cancer cells. This was proven to occur via inhibiting the signaling pathway of $\mathrm{PI} 3 \mathrm{~K} / \mathrm{AKT} / \mathrm{mTOR}$ in vitro and in vivo with considerable safety profile [53].

\subsection{Pyridine and Fused Pyridine Derivatives}

Most recently, Khalili et al. reported the design and synthesis of a new series of styrylimidazo[1,2-a]pyridine derivatives 30 (Figure 5) via reaction of cinnamaldehydes, 2-aminopyridines, and cyclohexyl/tert-butyl isocyanide mixture (Bienayme reaction). The synthesized compounds were screened against three breast cancer cell lines: MDA-MB-231, MCF-7, and T-47D using MTT assay. Most of the tested compounds displayed higher activity compared to the reference drug, etoposide. Fortunately, compound 30a (Figure 5) showed the highest activity against the three examined breast cancer cell lines with $\mathrm{IC}_{50}$ values of $12.12 \pm 0.54 \mu \mathrm{M}, 9.59 \pm 0.7 \mu \mathrm{M}$ and $10.10 \pm 0.4 \mu \mathrm{M}$, respectively. It is worth mentioning that the cytotoxic activity of the prepared styrylimidazo[1,2-a]pyridine derivatives is attributable to their ability to provoke apoptosis in the examined BC cell lines [54].

Moreover, Pang et al. prepared a novel series of pyrazolo[4,3-c] hexahydropyridine derivatives and studied their anti-proliferative activity against two breast cancer cell lines, MDA-MB-231 and MCF-7. The results showed that compound 31 (Figure 5) displayed excellent cytotoxic activity against MDA-MB-231 and MCF-7 with IC $_{50}$ values of $4.2 \mu \mathrm{M}$ and $2.4 \mu \mathrm{M}$, respectively, compared to standard drug 5-fluorouracil that showed $\mathrm{IC}_{50}$ values of $9.6 \mu \mathrm{M}$ and $4.8 \mu \mathrm{M}$, respectively [55]. Further mechanistic insights, via cell cycle analysis, acridine orange/ethidium bromide (A.O./Et.Br.) double staining, and TUNEL assay, suggested that the target pyrazolo[4,3-c]hexahydropyridine derivatives could promote apoptosis in the tested BC cell lines.

Furthermore, Prasad et al. developed novel pyridine-bearing phosphonate esters 32 (Figure 5) as potential aromatase inhibitors. The design of these derivatives was performed utilizing computational docking analysis studies which revealed their ability to form strong $\mathrm{H}$-bonds with the essential amino acid residues in the enzyme active site with considerable low energy. Accordingly, this serves as the mechanistic explanation for the significant 
in vitro cytotoxic activity observed by the compounds against the MCF-7 breast cancer cell line [56].

As a continuous search for novel potent anti-breast cancer agents, Rahnamay et al. reported the design and synthesis of a novel series of pyranopyridine derivatives. The antiproliferative screening of the synthesized compounds identified compound 33 (Figure 5) as an effective cytotoxic agent against the MCF-7 cell line, with an $\mathrm{IC}_{50}$ value of $60 \mu \mathrm{M}$. Further cell cycle analysis, A.O./Et.Br. double staining and DNA fragmentation assay proved that compound 33 exerted its anti-proliferative activity by apoptosis induction in MCF-7 cells [57].<smiles>[R]c1ccnc(N)c1</smiles>

28

$\mathrm{R}_{1}=\mathrm{H}, \mathrm{Me}, \mathrm{Cl}$

$\mathrm{R}_{2}=\mathrm{H}, \mathrm{OMe}$

$\mathrm{R}_{3}=\mathrm{t}-\mathrm{BU}$, cyclohexyl

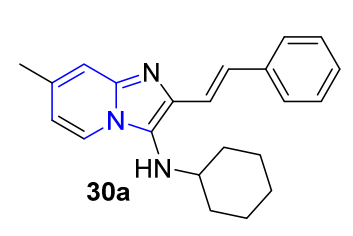<smiles>[R2]c1ccc(/C=C/C=O)cc1</smiles>

29

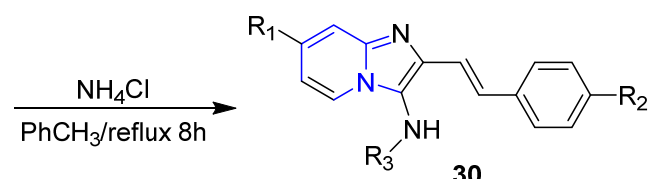

30
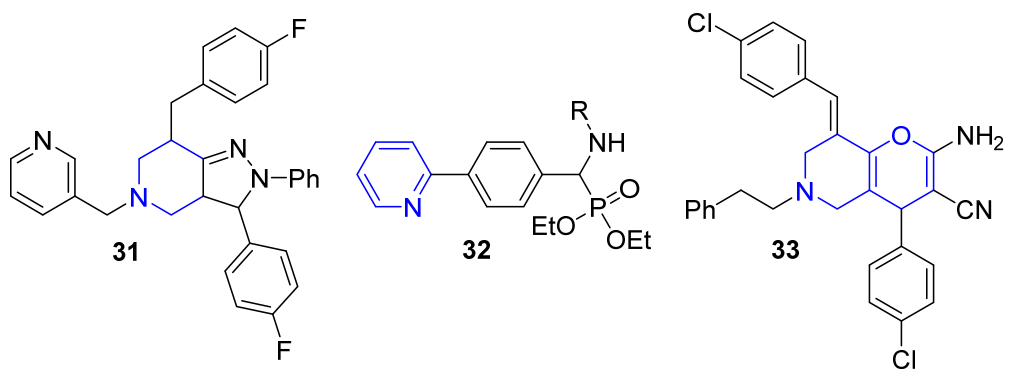

Figure 5. Certain reported pyridine and fused pyridine compounds as anti-breast cancer agents.

\subsection{Pyridazine-Based Small Molecules}

In 2020, Sabt et al. designed and synthesized a new series of 3,6-disubstituted pyridazines (Figure 6) as promising antitumor agents targeting cyclin-dependent kinase 2 (CDK-2). Furthermore, the target 3,6-disubstituted pyridazines were in vitro evaluated for their growth inhibitory activity against three human cancer cell lines. The results showed that the compounds displayed selective cytotoxic activity against breast cancer cell lines, MDA-MB-231 and T-47D, while they revealed weak activity against ovarian cancer cell line SKOV-3. Among all these derivatives, compound 34 (Figure 6) was grasped as a potent cytotoxic agent against MDA-MB-231 and T-47D, with $\mathrm{IC}_{50}$ values of $0.99 \pm 0.03$ and $0.43 \pm 0.01 \mu \mathrm{M}$, respectively [58].

Previously, Kim et al. developed a new series of 3-alkylamino-6-allylthio-pyridazine derivatives by using 3,6-dichloropyridazine as starting material and were evaluated in cytotoxicity assays. Among these, compounds $\mathbf{3 5}$ and $\mathbf{3 6}$ (Figure 6) revealed higher potencies against the MCF-7 cell line compared to the standard drug $5 \mathrm{FU}$ with $\mathrm{IC}_{50}$ values of $17.2 \mu \mathrm{g} / \mathrm{mL}, 17.16 \mu \mathrm{g} / \mathrm{mL}$ and $477.47 \mu \mathrm{g} / \mathrm{mL}$, respectively [59]. Moreover, the authors prepared another series from 3-allylseleno-6-alkylthiopyridazines to investigate their biological activity as anti-breast cancer agents. For the derivatives tested, 3-allylseleno6-pentylthiopyridazine 37 (Figure 6) exhibited the highest cytotoxic activity compared to 5FU against the MCF-7 cell line [60]. On the other hand, a new series of arylpyridazines was designed, synthesized and studied as anti-proliferative agents against seven cancer cell lines: HuH7, CaCo-2, MDA-MB-231, HCT116, PC3, NCI-H727 and HaCaT. Compound 38 (Figure 6) displayed favorable potent activity against all the tested cell lines with an $\mathrm{IC}_{50}$ value of $0.1 \mu \mathrm{M}$. Further mechanistic investigations revealed the ability of the target pyridazine derivatives to affect p44/42 and Akt-dependent signaling pathways [61]. 


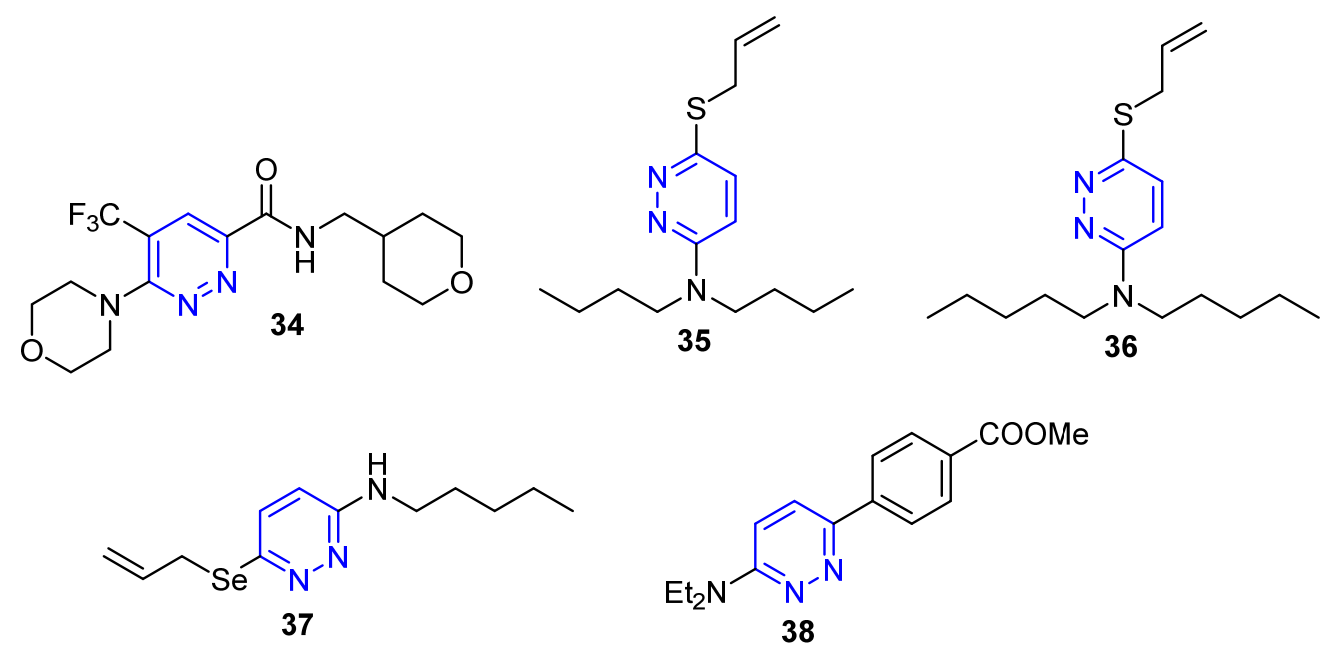

Figure 6. Pyridazine derivatives as anti-breast cancer agents.

\subsection{Non-Fused and Fused Pyrimidines Moiety}

Surveying the literature revealed that the pyrimidine entity serves as a promising scaffold for designing potent anti-breast cancer agents [62]. Accordingly, new derivatives of thieno[2,3- $d$ ]pyrimidine were synthesized and screened against MCF-7 breast cancer cell line. The results displayed that compound 42 (Figure 7) showed the most cytotoxic activity against breast cancer cell line MCF-7 with low $\mathrm{IC}_{50}$ with significant safety margin against non tumerogenic MCF-10A cell line. Further in vitro studies disclosed that the aforementioned compound exerts its cytotoxic activity through inhibition of pim-1 kinase [63].

In 2019, Wang et al. reported the design and synthesis of a series of isolongifoleno pyrimidine derivatives through three steps using fragment-based design approach. The anti-proliferative effect against breast cancer MCF-7 cell was estimated. Among all the tested pyrimidine derivatives, compound 45 (Figure 7) bearing 4-fluorophenyl and 4-methylphenyl moieties displayed maximum cytotoxic activity with $\mathrm{IC}_{50}$ value of $0.33+0.24 \mu \mathrm{M}$. Moreover, compound 45 was proven to induce apoptosis in the aforementioned cancer cells by boosting ROS generation [64].

Moreover, new compounds of camphor-based pyrimidine derivatives were synthesized and studied for their anticancer activity against three cancer cell lines: MDA-MB231, A549 and RPMI-8226. According to the results of cytotoxicity assays, compound 48 (Figure 7) possessed the most potent cytotoxic activity against the tested cancer cell lines compared to the reference drug etoposide with much lower cytotoxic effect against normal cell GES-1 ( IC $_{50}>50 \mu \mathrm{M}$ vs. $8.89 \mu \mathrm{M}$ ). Noteworthy, the cytotoxic activity of compound 48 was attributable to the ROS-mediated mitochondrial apoptosis [65].

In addition, Zhang et al. reported the synthesis of 3-(phenylethynyl)- $1 H$-pyrazolo[3,4d]pyrimidin-4-amine derivatives (Figure 7) and the evaluation of their anti-proliferative activity towards the TNBC MDA-MB-231 cell line. Among the tested compounds, compound 49 (Figure 7) exhibited significant cytotoxic activity against the MDA-MB-231 TNBC cancer cell line. Moreover, it proved to be a potent multikinase inhibitor against Src with an $\mathrm{IC}_{50}$ value in the nanomolar range $(0.9 \mathrm{nM})$, and against MAPK signaling protein kinases including B-RAF and C-RAF. Compound 49 also was proven to provoke apoptosis in the examined cancer cell line [66].

A series of pyrimidine $\mathrm{N}$ - and S-glycosides incorporating an oleyl residue were synthesized and evaluated against two cancer cell lines (MCF-7 and HepG2). The assay results outputs revealed that the tested compounds displayed moderate to high activities. Moreover, compounds $\mathbf{5 0}$ and $\mathbf{5 1}$ (Figure 7) exhibited the most potent activity against MCF-7 and HepG2 cancer cell lines with $\mathrm{IC}_{50}$ value of $13.2 \mu \mathrm{M}$ and $24.9 \mu \mathrm{M}$, and $22.6 \mu \mathrm{M}$ and $16.2 \mu \mathrm{M}$, respectively [67]. 

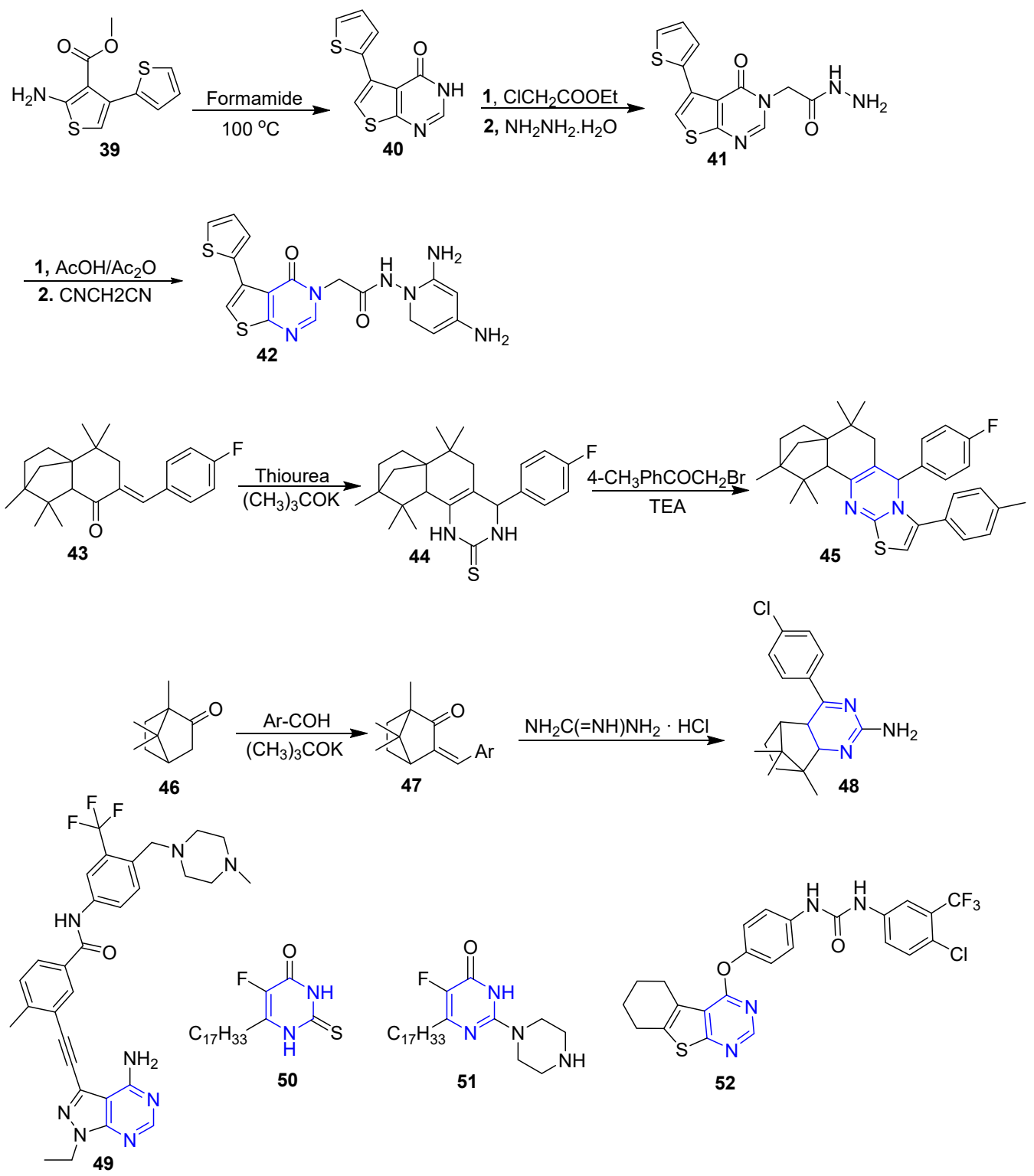

Figure 7. Non-fused and fused pyrimidines-based small molecules as anti-breast cancer agents.

Moreover, a novel thienopyrimidine derivative (52) (Figure 7) was designed and synthesized as a VEGFR-2 tyrosine kinase inhibitor, a potential activity target of breast cancer. Thienopyrimidine 52 showed potent activity against $\mathrm{T} 47 \mathrm{D}\left(\mathrm{IC}_{50}=6.9 \pm 0.04 \mu \mathrm{M}\right)$ and MDA-MB-231 $\left(\mathrm{IC}_{50}=10 \pm 0.04 \mu \mathrm{M}\right)$. Additionally, compound 52 significantly inhibited VEGFR-2 by a percentage of $65 \%$, and it down-regulated the level of VEGF in the MCF7 cancer cell line by $30.4 \%$ which explained the molecular basis of the observed antiproliferative activity [68].

\subsection{Imidazole and Benzimidazole Derivatives}

Meenakshisundaram et al. synthesized a new series of imidazoles and imidazopyridines via Schiff base reaction with a possibility of potential anticancer activity. The target compounds were evaluated for antitumor activities. Among these, compounds 55 and 56 were the most active against the three tested cancer cell lines: MDA-MB-231, HeLa and ACHN. Selectively, both compounds 55 and 56 (Figure 8) displayed effective significant activity against the breast cancer cell line MDA-MB-231 (55, GI $\mathrm{I}_{50}=0.30 \mu \mathrm{M} ; \mathbf{5 6}$, $\left.\mathrm{GI}_{50}=0.43 \mu \mathrm{M}\right)[69]$. 

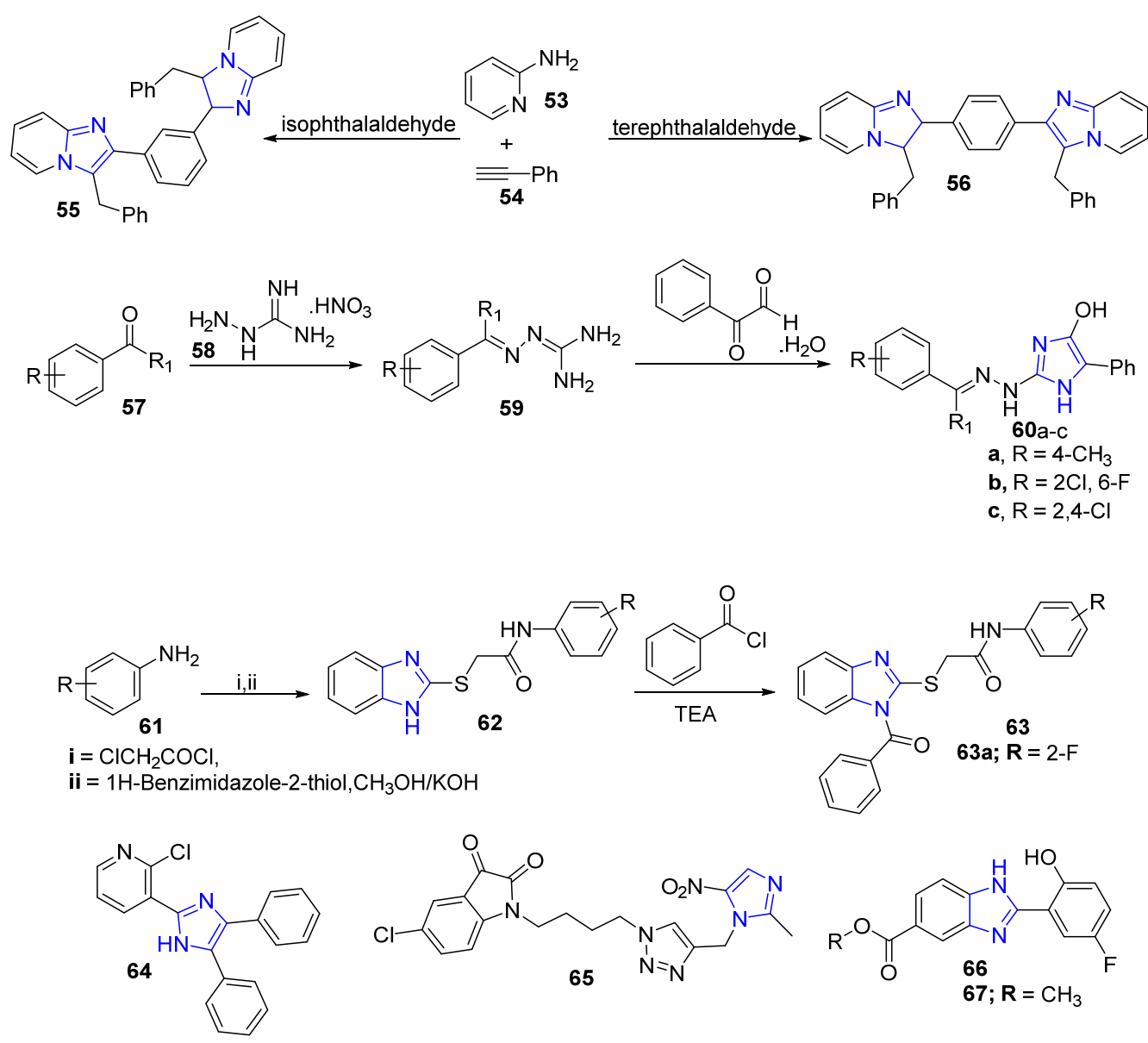

Figure 8. Imidazole and benzimidazole compounds as anti-breast cancer agents.

The imidazole derivatives 60a-c (Figure 8) were synthesized through a condensation reaction between phenylglyoxal monohydrate with guanidnyl hydrazone. All target imidazoles were screened for human breast cancer cell line MCF-7 by using the MTT assay. Results showed that compounds $\mathbf{6 0 a}-\mathbf{b}$ (Figure 8) revealed higher cytotoxic activities compared to the reference drug (5-FU and irinocam) against the aforementioned cancer cell line giving insight that this scaffold can serve as a good platform for designing novel anti-breast cancer agents [70]. Moreover, new benzoimidazole derivatives 63 (Figure 8) were designed and synthesized to explore their anti-proliferative activity. In particular, compound 63a (Figure 8) exhibited the highest anticancer activity $\left(\mathrm{IC}_{50}=0.0047 \mu \mathrm{M} / \mathrm{mL}\right.$ ) against the MCF-7 cancer cell line with almost equal cytotoxicity compared to the reference drug tamoxifen [71].

Mohan et al. [72] synthesized new compounds based on imidazole scaffold as anti-BC agents through inhibition of the signaling pathway of PI3K/Akt/mTOR. Anticancer results revealed that compound 64 (Figure 8) demonstrated potent activity against two breast cancer cell lines, MDA-MB-231 and MCF-7. Additionally, a novel series of imidazole-isatinthiosemicarbazone and 1,2,3-triazole tethered imidazole-isatin hybrids were designed, synthesized and studied as anti-breast cancer agents (Figure 8). It was found that compound 65 was the most potent counterpart with the value of $\mathrm{IC}_{50} 26.12 \mu \mathrm{M}$ and $54.25 \mu \mathrm{M}$ against MDA-MB-231 and MCF-7 cell lines, respectively [73].

Karthikeyan et al. [74] synthesized a new series of benzimidazole carboxylic acids and their esters 66 (Figure 8) as novel potential anti-BC agents. In particular, ester 67 (Figure 8) possessed the strongest anti-proliferative activity against three breast cancer cell lines, MCF-7, MDA-MB-231 and MDA-MB-468, with the value of growth inhibition $\mathrm{GI}_{50}=0.18$, $4.09 \mu \mathrm{M}$ and $6.23 \mu \mathrm{M}$, respectively. 


\subsection{Coumarin Derivatives}

Ahmed et al. designed and synthesized twenty-five coumarin-based derivatives and evaluated their anti-proliferative activity against the MCF-7 cancer cell line and their VEGFR-2 kinase inhibitory activity. Compounds 68 and 69 (Figure 9) displayed a maximal significant response against the MCF-7 cancer cell line with an $\mathrm{IC}_{50}$ value of $1.24 \mu \mathrm{M}$ and $1.65 \mu \mathrm{M}$, respectively, comparable to that of the reference drug staurosporine $\left(\mathrm{IC}_{50}=8.81 \mu \mathrm{M}\right)$. Furthermore, compound 68 was able to inhibit VEGFR-2 kinase activity at an $\mathrm{IC}_{50}$ of $0.36 \mu \mathrm{M}$ which is comparable for that recorded by staurosporine $\left(\mathrm{IC}_{50}=0.33 \mu \mathrm{M}\right)[75]$.

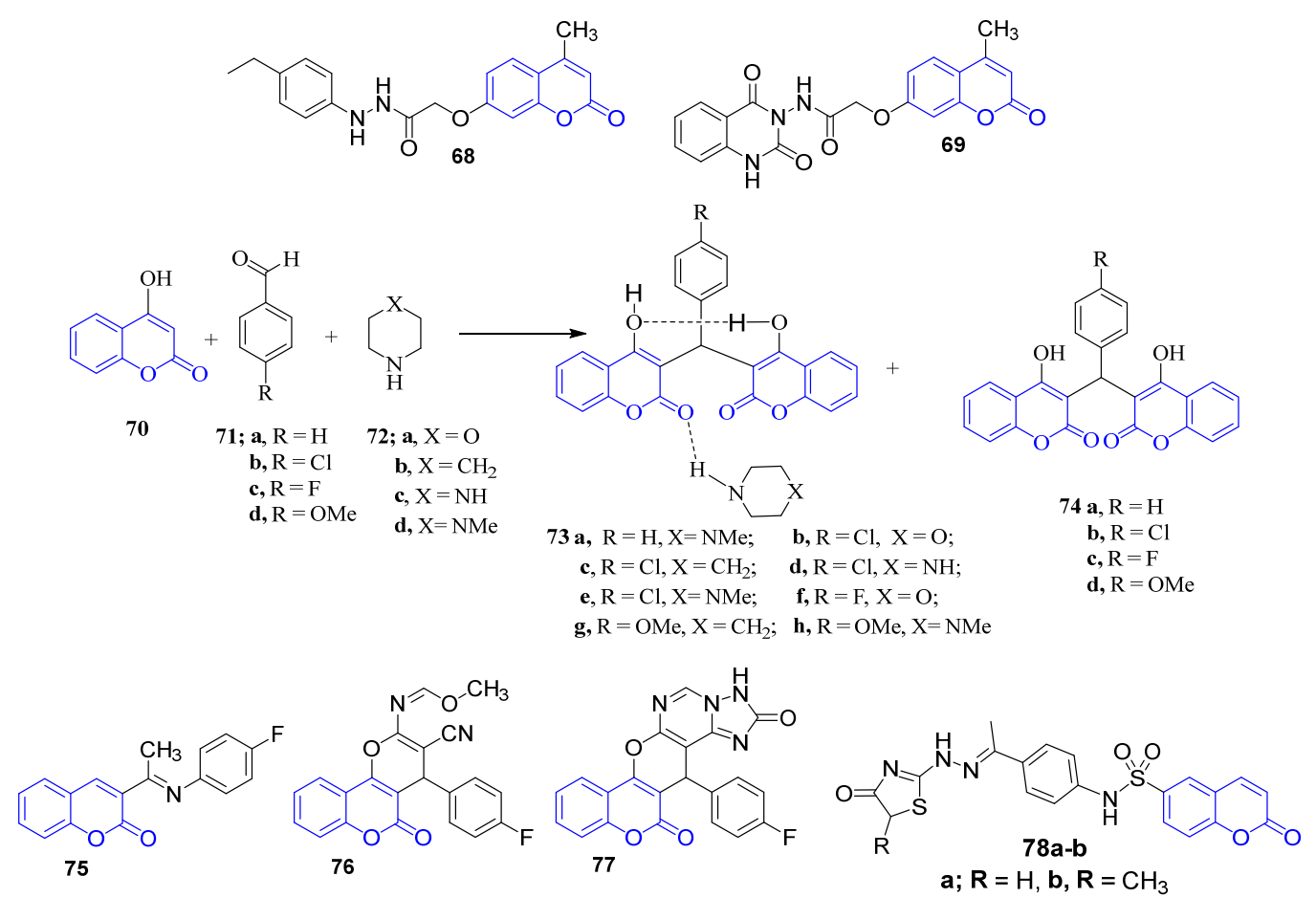

Figure 9. Coumarin-based small molecules as anti-breast cancer agents.

The condensation reactions of 4-hydroxycoumarin, aldehydes and cyclic secondary amines yielded the bis-coumarins derivatives $\mathbf{7 3}$ and $\mathbf{7 4}$ (Figure 9). A cytotoxicity of the novel coumarin derivatives against the MCF-7 breast cancer cell line was evaluated and displayed that compound 73 has a promising cytotoxic activity against MCF-7 with an $\mathrm{IC}_{50}$ value of $12.1 \mu \mathrm{g} / \mathrm{mL}$ which is superior to that of the reference drug doxorubicin with an $\mathrm{IC}_{50}$ value of $16.2 \mu \mathrm{g} / \mathrm{mL}$. A molecular docking study for the target compounds identified Topoisomerase IIa as a potential target [76].

New compounds of fluorinated coumarin-based derivatives were synthesized, and their anti-proliferative activity was studied on MCF-7 and HeLa in addition to their potential to inhibit VEGFR-2. Compounds 75, 76 and 77 (Figure 9) exhibited higher inhibition activity against the MCF-7 cell line $\left(\mathrm{IC}_{50}=8.30 \mu \mathrm{g} / \mathrm{mL}, 8.28 \mu \mathrm{g} / \mathrm{mL}\right.$, and $7.90 \mu \mathrm{g} / \mathrm{mL}$, respectively). Furthermore, these coumarins unveiled superior inhibitory activity against VEGFR-2 with inhibition percentage of 94\% [77]. In 2018, Sabt et al. developed new series of coumarin sulfonamide derivatives and evaluated their anticancer activity. Among all these derivatives, compounds 78a-b (Figure 9) $\left(\mathrm{IC}_{50}=10.95 \pm 0.96 \mu \mathrm{M}\right.$ and $\mathrm{IC}_{50}=10.62 \pm 1.35 \mu \mathrm{M}$ ) exhibited significant cytotoxic activity against breast cancer MCF-7 cell lines [78]. Interestingly, the target coumarin-6-sulfonamides efficiently promote the mitochondrial apoptosis. 


\subsection{Tetrazole-Bearing Derivatives}

Dileep and coworker described a novel series of tetrazole-bearing ciprofloxacin and pipemidic acid derivatives and screened their anti-proliferative activity against the MDAMB-231 breast cancer cell line. Based on the results assay, compounds $79 \mathbf{a}-\mathbf{b}$ and $\mathbf{8 0 a}-\mathbf{b}$ (Figure 10) displayed the most potent cytotoxic activity with growth inhibition ranging $\left(\mathrm{GI}_{50}=0.08-0.09 \mu \mathrm{M}\right)$, which is significantly more potent than the reference drug tamoxifen $\left(\mathrm{GI}_{50}=0.24 \mu \mathrm{M}\right)$ against the MDA-MB-231 cell line [79].<smiles>[R]n1nnnc1SCCC(=O)N1CCN(c2cc3c(cc2F)c(=O)c(C(=O)O)cn3C2CC2)CC1</smiles><smiles>[R]n1nnnc1SCCC(=O)N1CCN(c2ncc3c(=O)c(C(=O)O)cn(CC)c3n2)CC1</smiles>

a, $\mathrm{R}=$<smiles>CCCc1ccccc1</smiles>

a, $R=$<smiles>CC(C)(C)c1ccccc1</smiles><smiles>Cc1ccc(F)c(F)c1F</smiles><smiles>[R]c1ccccc1/C=N\NC(=O)Cn1nnnc1-c1ccc2c(c1)OCO2</smiles>

81a-d: a, $\mathrm{R}=2-\mathrm{NO}_{2}$;

b, $\mathrm{R}=3-\mathrm{NO}_{2}$

c, $\mathrm{R}=4-\mathrm{NO}_{2}$

d, $\mathrm{R}=2,4-\left(\mathrm{OCH}_{3}\right)_{2}$<smiles>[R]c1ccccc1NC(=O)c1ccccc1-c1nnn(-c2ccccc2)n1</smiles>

82a-c: a, $\mathrm{R}_{1}=2-\mathrm{CF}_{3}, \quad \mathrm{R}_{2}=4-\mathrm{OCH}_{3}$; b, $\mathrm{R}_{1}=4-\mathrm{nC}_{3} \mathrm{H}_{7}, \mathrm{R}_{2}=4-\mathrm{CH}_{3}$; c, $\mathrm{R}_{1}=4-\mathrm{OCH}_{3} ; \mathrm{R}_{2}=\mathrm{nC}_{3} \mathrm{H}_{7}$

Figure 10. Tetrazole-bearing compounds as anti-breast cancer agents.

In another study, Arshad and coworkers prepared a series of tetrazole-based derivatives and evaluated the biological activity of these compounds against MCF-7 (ER positive), MDA-MB-231 and ZR-75 (ER negative) breast cancer cell lines. The results showed that compounds 81a-c (Figure 10) exhibited potent inhibitory activity against MCF-7 cells, while compound 81d (Figure 10) revealed potent activity against both ZR-75 and MDA-MB-231 cell lines [70]. Furthermore, compounds 82a-c unveiled higher potent selectivity toward breast cancer resistance protein (BCRP/ABCG2) than the reference Ko143 (Figure 10) [80].

\subsection{Indole- and Oxindole-Based Anti-Breast Cancer Agents}

Indole and oxindole moiety, among the widest-spread heterocycles in nature, are used as a building block for many pharmaceutical agents, especially in the discovery of new antitumor agents [81-84]. For example, Eldehna et al. in 2018 [85] developed a new series of [(3-indolylmethylene) hydrazono]indolin-2-ones derivatives and investigated their cytotoxic activity. Compound 85 (Figure 11) was the most active derivative against the MCF-7 cell line with an $\mathrm{IC}_{50}$ value of $1.04 \pm 0.08 \mu \mathrm{M}$ which is higher than the reference drug doxorubicin $\left(\mathrm{IC}_{50}=2.57 \pm 0.18 \mu \mathrm{M}\right)$ and was capable of inducing apoptosis and cell cycle arrest at the G2/M phase. Moreover, Kaur et al. developed a new series of indole hybridized diazenyl derivatives. Among the tested derivatives, compounds 86 and 87 (Figure 11) possessed promising activity against breast cancer cell line MDA-MB-231, in addition to being safe by exhibiting very low cytotoxic activity against the normal cell line [86]. 


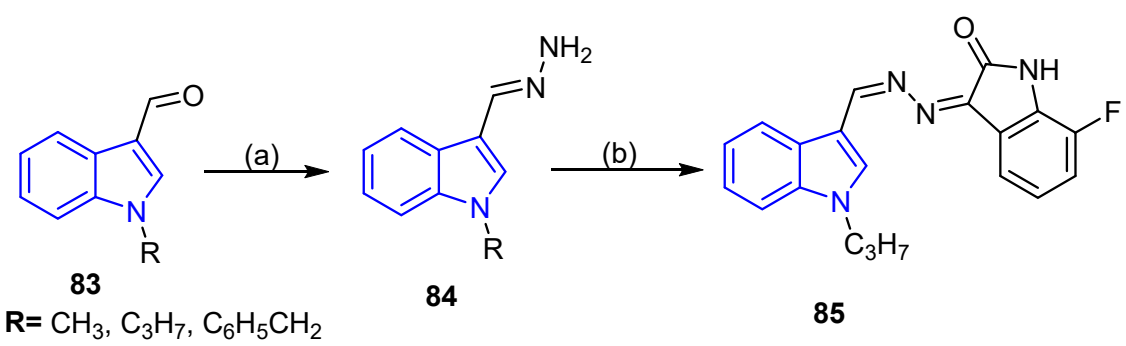<smiles>CC(=NCCCc1cccc2ccccc12)c1ccc(N=Nc2c[nH]c3ccccc23)cc1</smiles><smiles>[R]c1cccc(CCn2c3c(c4c2C(=O)c2cccc([R7])c2-4)C(=O)CC(C)C3)c1[R]</smiles>

Figure 11. Indole and oxidole compounds as anti-breast cancer agents.

Novel indole derivatives were also designed and synthesized to investigate their biological activity as casein kinase II (CK2) and ABCG2 inhibitors. The results revealed that the compounds having $\mathrm{N}^{5}$-isopropyl substituent on the $\mathrm{C}$-ring $(\mathbf{8 8 a} \mathbf{a}-\mathbf{c})$ were the most potent inhibitors of casein kinase II (CK2) $\left(\mathrm{IC}_{50}=0.17-0.36 \mu \mathrm{M}\right)$ (Figure 11), while compounds containing $\mathrm{N}^{5}$-phenethyl substituent on the $\mathrm{C}$-ring $(\mathbf{8 9} \mathbf{a}-\mathbf{c})$ displayed significant activity against breast cancer resistance protein $\mathrm{ABCG} 2\left(\mathrm{IC}_{50}=0.21-0.31 \mu \mathrm{M}\right)$ (Figure 11) [87].

In 2015, Ma et al. synthesized a novel series of indole-benzothiazole derivatives and examined their antitumor activity against four cancer cell lines: HT29, H460, A549 and MDA-MB-231. The assay results showed that compound 90 (Figure 11) displayed potent cytotoxic activity against MDA-MB-231 with $\mathrm{IC}_{50}$ values of $0.024,0.29,0.84$ and $0.88 \mu \mathrm{M}$, respectively; this was explained by their ability to activate procaspase-3, besides arresting the cell cycle [88].

The reaction of 2-substituted indoles with halogeno-quinone produced indolylquinone derivatives which were designed as potential anti-breast cancer agents. The results exhibited that compound 93a displayed significant potency toward MCF-7 $\left(\mathrm{IC}_{50}=2.29 \mu \mathrm{g} / \mathrm{mL}\right)$, while compound $93 \mathbf{b}$ was the most active derivative against MDA-MB-231 $\left(\mathrm{IC}_{50}=3.99 \mu \mathrm{g} / \mathrm{mL}\right)$ (Figure 12) [89]. Fluorescence microscopy analysis hinted that indolylquinone derivatives inhibited the growth of $\mathrm{BC}$ via triggering apoptotic cell death.

Furthermore, aryl methyl ring substituted analog of 3,3'di Indolyl methane (DIM), Phemindole 94 (Figure 12), was synthesized and evaluated as an anticancer agent toward triple-negative breast cancer (TNBC). This compound exhibited potent activity against MDA-MB-231 cell lines with induction of apoptosis in MDA-MB-231 cells and have antimigration activity by focal adhesion kinase control phosphorylation in the aforementioned cell line [90]. 

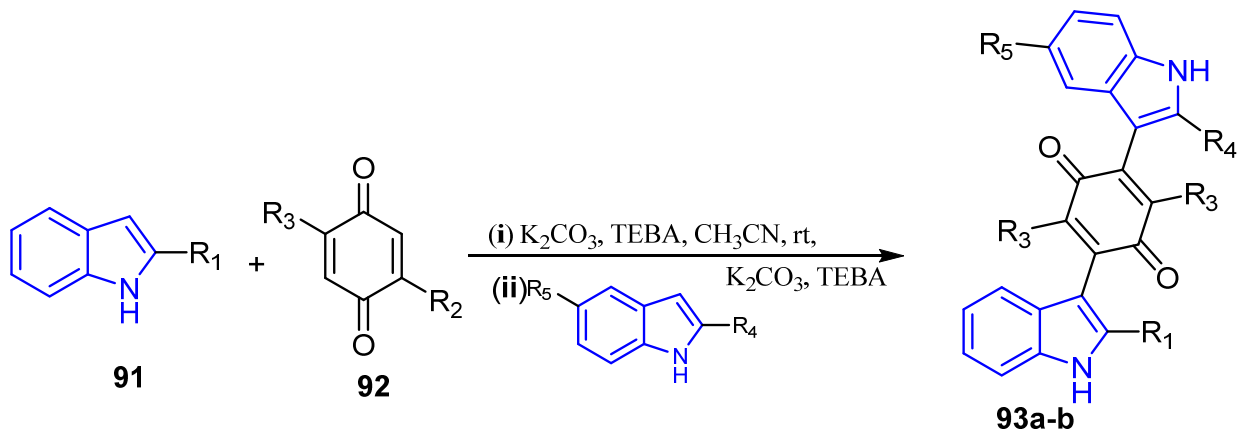

a, $\mathrm{R}_{1}=\mathrm{CH}_{3}, \mathrm{R}_{2}=\mathrm{R}_{3}=\mathrm{Cl}, \mathrm{R}_{4}=\mathrm{Ph}, \mathrm{R}_{5}=\mathrm{H}$

b, $\mathrm{R}_{1}=\mathrm{C}_{6} \mathrm{H}_{5}\left(\mathrm{CH}_{3}\right) p, \mathrm{R}_{2}=\mathrm{R}_{3}=\mathrm{Br}$, $\mathrm{R}_{4}=\mathrm{CH}_{3}, \mathrm{R}_{5}=\mathrm{OCH}_{3}$

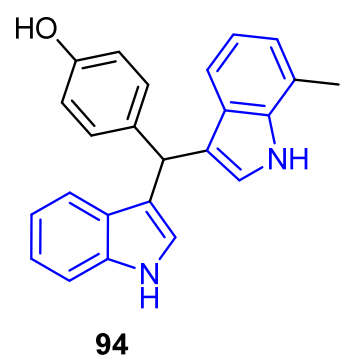<smiles>[X]c1ccc(/N=C/C2C(=O)N(CC(=O)Nc3cc([R2])ccc3[R])c3ccccc32)cc1</smiles><smiles></smiles>

a, $\mathrm{R} 1=\mathrm{R} 2=\mathrm{CH}_{3}, \mathrm{X}=\mathrm{H}$

b, $\mathrm{R} 1=\mathrm{CH}_{3}, \mathrm{R} 2=\mathrm{H}, \mathrm{X}=3-\mathrm{Cl}$;

c, $\mathrm{R} 1=\mathrm{R} 2=\mathrm{H}, \mathrm{X}=4-\mathrm{Cl}$;

d, R1 $=\mathrm{CH}_{3}, \mathrm{R} 2=\mathrm{H}, \mathrm{X}=4-\mathrm{Cl}$

Figure 12. Indole and oxidole compounds as anti-breast cancer agents.

In 2016, Debnath et al. synthesized ten new oxindole analogs. Cytotoxicity evaluation revealed that especially compounds $\mathbf{9 5 a}-\mathbf{d}$ displayed potent activity against MCF-7 (Figure 12) with the value of growth inhibition $\left(\mathrm{GI}_{50}<0.02 \mu \mathrm{M}\right)$ comparative to activity with reference drug adramycin (doxorubicin). A molecular docking into the EGFR biding site (PDB ID 1M17) has highlighted EGFR kinase as a possible target for the oxindole derivatives [91].

Karthikeyan et al. developed new indolin-2-ones derivatives bearing oxindole and chalcones moieties as anti-proliferative and breast cancer agents. All of the synthesized compounds exhibited promising anticancer activity against the tested cell lines. In particular, 5-chloro-3-(2-(3,4-dimethoxyphenyl)-2-oxoethylidene) indolin-2-one (96) with $\mathrm{GI}_{50}=3.59$, 4.76 and $8.54 \mu \mathrm{M}$ (Figure 12) showed potent cytotoxic activity toward the three tested breast cancer cell lines, MCF-7, MDA-MB-468 and MDA-MB-231, respectively [92].

\subsection{Triazine-Based Derivatives as Anti-Breast Cancer Agents}

El-Faham et al. developed novel derivatives of di- and tri-substituted s-triazine as potential target of MCF-7 (ER+) and MDA-MB-231 (ER-) human BC cell lines. Compounds 97 and 98 (Figure 13) displayed potent anticancer activity against the MCF-7 cancer cell line with $\mathrm{IC}_{50}$ values less than $1 \mu \mathrm{M}(0.77 \pm 0.01$ and $0.1 \pm 0.01 \mu \mathrm{M}$, respectively). Furthermore, compound 99 (Figure 13) exhibited the better cytotoxic activity against MDA-MB-231 with an $\mathrm{IC}_{50}$ value of $6.49 \pm 0.04 \mu \mathrm{M}$ [93]. The study outcomes suggested that target triazines exerted their anticancer action in human BC cells through targeting the estrogen and progesterone receptors. 
<smiles>CCN(CC)c1nc(Nc2ccc(C#N)cc2)nc(OC)n1</smiles><smiles>CCOC(=O)C1=C(C)C(c2nc(Nc3ccc(F)cc3)nc(Nc3ccc(F)cc3)n2)C(=S)NC1c1ccc(O)cc1</smiles>

Figure 13. Triazine compounds as anti-breast cancer agents.

Moreover, Srivastava et al. utilized a three-component reaction using $\mathrm{Bi}\left(\mathrm{NO}_{3}\right)_{3}$ as a catalyst in one-pot synthesis approach to prepare some hybridized analogues of monastrol1,3,5-triazine. The synthesized compounds exhibited anti-proliferative activity selectively against the MCF-7 breast cancer cell line where the most active compound $\mathbf{1 0 0}$ (Figure 13) displayed an $\mathrm{IC}_{50}$ value of $41.5+0.31 \mu \mathrm{M}$. Moreover, all the tested compounds proved to be non-toxic to the normal cell line MCF-12A. Interestingly, the observed anti-proliferative activity was justified by the marked inhibition of EGFR tyrosine kinase tested in vitro and in vivo by all the synthesized compounds. Fortunately, compound $\mathbf{1 0 0}$ was able to inhibit the target enzyme by $96.4 \%$ [94].

In 2020, Hu et al. published interesting research where they designed and synthesized novel 1,3,5-triazine ring bearing acrylic acid or acrylic amide side chains as selective estrogen receptor degraders (SERDs) besides their possessing estrogen receptor antagonism properties. Degrading estrogen receptors is a new and effective approach for combating breast cancer. Unfortunately, only few scaffolds proved to be beneficial as SERDs. Through their research, $\mathrm{Hu}$ et al. proved that all the target compounds possess marked anti-BC activity. Compound 101 (XHA1614) (Figure 13) exhibited potent remarkable cytotoxicity versus Ishikawa and MCF-7 cells ( $\mathrm{IC}_{50}=3.11 \mu \mathrm{M}$ and $3.15 \mu \mathrm{M}$, respectively) and also led to significantly degrading ER level at $1 \mathrm{nM}$ in Western blotting assay, beside its antagonistic activity against progesterone receptor in MCF-7 cells. Accordingly, the triazine scaffold proved to be a promising candidate as SERD for the management of breast cancer [95]. Moreover, in the same year, Junaid et al. prepared a novel series of 6, $N^{2}$-diaryl-1,3,5triazine-2,4-diamine derivatives to screen the cytotoxic activity against three breast cancer cell lines: MDA-MB-231, MCF-7 and SKBR-3. The results indicated that the synthesized compounds have a significant activity against MDA-MB-231; in particular, compound 102 (Figure 13) exhibited excellent anti-proliferative activity with $\mathrm{IC}_{50}=1 \mathrm{nM}$ without cytotoxicity against the normal cell of MCF-10A breast [96].

\subsection{Oxadiazole-Bearing Small Molecules as Anti-Breast Cancer Agents}

A series of novel substituted 2-(phenoxymethyl)-5-phenyl-1,3,4-oxadiazole derivatives was prepared and screened for cytotoxicity against BC cells. The target compounds unveiled good activity towards the tested cell lines, in particular, compound 103 (Figure 14), the most potent derivatives with $\mathrm{IC}_{50}=10.25 \pm 2.5$ and $10.51 \pm 1.9 \mu \mathrm{M}$ against BC MCF-7 and MDA-MB-453 cell lines, respectively. Moreover, the target 2-(phenoxymethyl)-5phenyl-1,3,4-oxadiazoles revealed their ability to induce apoptosis [97].

Gamal El-Din et al. developed a series of 1,3,4-oxadiazole derivatives bearing a sulfonamide moiety in order to screen their anticancer activity against a panel of 58 cancer cell lines of nine different types of cancer. Compound 104 (Figure 14) showed a powerful 
cytotoxic effect against tested cell lines, especially the T-47D breast cancer cell line with growth inhibition of $90.47 \%$ at $10 \mu \mathrm{M}$, compared to the reference drugs Paclitaxel and Gefitinib [98]. Additionally, a novel series of coumarin linked to 1,3,4-oxadiazole moiety was synthesized and screened as anti-BC agents against two breast cancer cell lines, MCF-7 and MDA-MB-231. Compound 105 (Figure 14) displayed the most effective potency against MCF-7 cells with an $\mathrm{IC}_{50}$ value $<5 \mu \mathrm{M}$ which is about 1.4 times more potent than the reference drug tamoxifen [99].<smiles>COc1ccc(S(=O)(=O)Nc2ccc(OCc3nnc(-c4ccc(Cl)cc4)o3)c(F)c2)cc1</smiles><smiles>Cc1cc(OCc2nnc(SCc3ccc(Cl)cc3Cl)o2)cc2oc(=O)cc(C)c12</smiles>

Figure 14. Oxadiazole compounds as anti-breast cancer agents.

\subsection{Thiazolidine Derivatives}

Recently, a new series of thiazolidinone derivatives was synthesized to investigate their bioactivity as anti-breast cancer agents. The results exhibited that compound 106 (Figure 15) revealed to be the most active compound with $\mathrm{IC}_{50}$ values of $1.9 \pm 1.15$, $5.4 \pm 1.13$ and $6.5 \pm 1.16 \mu \mathrm{M}$ against MDA-MB-231, HepG2 and HT-29, respectively. This compound unveiled a promising anticancer agent against TNBC which induces apoptosis via arresting cell cycle at G1/S phase, beside inhibition of angiogenesis [100]. In addition, a new family of 2,3-thiazolidin-4-one derivatives was reported as effective anti-BC agents. Compounds 107a-b (Figure 15) showed potent cytotoxicity towards MCF-7 cells, while compounds 107c-e (Figure 15) showed remarkable activity against SKBR3 cells [101].<smiles>O=C(NN1C(=O)CSC1c1ccc([N+](=O)[O-])o1)c1ccccc1Sc1ccccc1</smiles><smiles>[R][R]1cccc(N2C(=O)CSC2c2ccccc2)c1</smiles>

107a, $\mathrm{R}=4-\mathrm{OH}, \mathrm{R}_{2}={ }_{3}, 4-\mathrm{OMe}$<smiles>COc1cc(/C=C2\SC(=O)N(CN3CCOCC3)C2=O)cc(OC)c1OC</smiles>

b, $\mathrm{R}_{1}=4-\mathrm{OH}, \mathrm{R}_{2}=4-\mathrm{Cl}$;

c, $\mathrm{R}_{1}=\mathrm{R}_{2}=\mathrm{H}$;

d, $R_{1}=4-M e, R_{2}=2,3-$ naphthyl;

e, $R_{1}=4-\mathrm{Me}, \mathrm{R}_{2}=3,4,5-\mathrm{OMe}$<smiles>CCOC(=O)CN1C(=O)S/C(=C\c2cc(OC)c(OC)c(OC)c2)C1=O</smiles><smiles>COc1cc(/C=C2\SC(=O)N(CC#N)C2=O)cc(OC)c1OC</smiles>

Figure 15. Thiazolidine derivatives as anti-breast cancer agents. 
El-Kashef et al. synthesized 3,5-disubstituted thiazolidine-2,4-dione derivatives and evaluated their anti-proliferative potential against MCF-7 and MDA-MB-231 cancer cell lines using MTT assay. The results displayed that compounds 108, 109 and 110 (Figure 15) were the most potent against MCF-7 with the $\mathrm{IC}_{50}$ value of $1.27,1.31$ and $1.50 \mu \mathrm{M}$, respectively. Furthermore, these three compounds, 108-110, induced apoptosis via reducing the expression levels of the anti-apoptotic protein Bcl-2 and enhancing the expression level of the pro-apoptotic protein Bcl-2 [102].

\subsection{Anti-Breast Cancer Agents Incorporating Naphthalene, Isoxazole and Pyrazole Moieties}

Wang et al. reported a new series of isoxazole-naphthalene derivatives as tubulin polymerization inhibitors. Their anti-proliferative activity was evaluated, and according to the assay results, compound 111 (Figure 16) bearing 4-ethoxy substitution at phenyl ring $\left(\mathrm{IC}_{50}=1.23 \pm 0.16 \mu \mathrm{M}\right)$ was the most potent against MCF-7 cancer cell line. Moreover, this compound $\mathbf{1 1 1}$ (Figure 16) has the ability to repress tubulin polymerization with an $\mathrm{IC}_{50}$ value of $3.4 \mu \mathrm{M}$, beside apoptosis induction, and ultimately cell cycle arrest $(\mathrm{G} 2 / \mathrm{M})$ phase [103]. In addition, the same research group has reported on another series from pyrazole-naphthalene derivatives. Compound 112 (Figure 16) with $\mathrm{IC}_{50}=2.78 \pm 0.24 \mu \mathrm{M}$ against MCF-7 cell line, was five times more potent than the reference drug cisplatin $\left(\mathrm{IC}_{50}=15.24 \pm 1.27 \mu \mathrm{M}\right)$. Furthermore, the aforementioned compound 112 (Figure 16) inhibited tubulin polymerization with $\mathrm{IC}_{50}$ value of $4.6 \mu \mathrm{M}$ in addition to induction of apoptosis and cell cycle arrest at the G2/M phase [104].<smiles>CCOc1ccc(-c2cnoc2-c2ccc(OC)c3ccccc23)cc1</smiles><smiles>CCOc1ccc(-c2cn[nH]c2-c2ccc(OC)c3ccccc23)cc1</smiles>

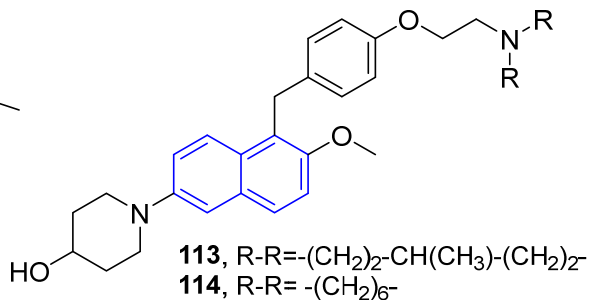<smiles>COC(=O)c1c(C)cc(OCc2cc(-c3ccc(Cl)cc3)no2)c(C)c1O</smiles>

115<smiles>[R]C1=NN([R])C(c2cn(-c3ccccc3)nc2-c2cccc([N+](=O)[O-])c2)C1</smiles><smiles>CC1=NN(c2ccc([N+](=O)[O-])cc2[N+](=O)[O-])C(=O)/C1=C\c1cn(-c2ccccc2)nc1-c1cccc([N+](=O)[O-])c1</smiles>
a, $\mathrm{R}=\mathrm{H}$,
$\mathbf{R}_{\mathbf{1}}=2$-Pyrroly
b, $\mathbf{R}=\mathrm{CH}_{3}, \quad \mathbf{R} 1=2$-Furanyl
c, $\mathrm{R}=\mathrm{Ph}, \quad \mathrm{R} 1=2-$ Furanyl
$\mathbf{d}, \mathbf{R}=\mathrm{CH}_{3} \mathrm{CO}, \mathbf{R}_{\mathbf{1}}=2$-Pyrroly
$\mathbf{e}, \mathbf{R}=\mathrm{CH}_{3} \mathrm{CO}, \mathbf{R} \mathbf{1}=2$-Furanyl

Figure 16. Naphthalene scaffold as anti-breast cancer agents.

Interestingly, Jha et al. designed and synthesized a new series of 6-(4-hydroxypiperidino) naphthalen-2-ol derivatives as selective estrogen receptor modulators (SERMs). Among all the tested compounds against the MCF-7 cancer cell line, compounds $\mathbf{1 1 3}$ and $\mathbf{1 1 4}$ (Figure 16) exhibited the higher cytotoxicity to oestrogen-responsive human breast cancer MCF-7 compared to the standard drug tamoxifen. Moreover, compound 114 (Figure 16) showed significant binding and antagonistic effects against human ER in an in vitro assay [105].

A novel series of sixteen methyl $\beta$-orsellinate-based 3,5-disubstituted isoxazole derivatives was synthesized by Reddy et al. The target compounds were screened in vitro for their anticancer activity against four cancer cell lines: IMR-32, DU-145, MIAPACA and MCF-7. Compound 115 (Figure 16) showed the highest inhibitory potency against the 
MCF-7 cell line $\left(\mathrm{IC}_{50}=7.9 \pm 0.07 \mu \mathrm{M}\right)$ with an induction of apoptosis and cell cycle arrest at the $\mathrm{G} 2 / \mathrm{M}$ phase [106].

A series of new pyrazole derivatives has been synthesized and screened in vitro as anti-BC targeting VEGFR-2 kinase. The assay results displayed that compounds 116a-e and 117 (Figure 16) exhibited the most potent activity against MCF-7 cell line with the value of $\mathrm{IC}_{50}$ ranging $(16.50-26.73 \mu \mathrm{M})$ compared to tamoxifen $\left(\mathrm{IC}_{50}=23.31 \mu \mathrm{M}\right)$. Furthermore, the synthesized compounds, especially $\mathbf{1 1 6} \mathbf{b}-\mathbf{e}$ and $\mathbf{1 1 7}$, showed significant inhibitory activities toward VEGFR-2 kinase with inhibition activity (70-79\%). In particular, compounds 116c, 116e and 117 unveiled the most inhibitory efficiency with $\mathrm{IC}_{50}$ in nanomolar range (913.51, 225.17, and $828.23 \mathrm{nM}$, respectively) in comparison to the reference drug sorafenib $\left(\mathrm{IC}_{50}=186.54 \mathrm{nM}\right)[107]$.

\subsection{Benzofuran Derivatives}

Benzofuran-based small molecules are well known in medicinal chemistry for their diverse, broad spectrum anticancer activity. Coskun et al. designed and synthesized a new series of benzofuran substituted chalcone derivatives and studied their in vitro antitumor activities by MTT assay. The results indicated that the tested compounds revealed cytotoxic activity against malignant MCF-7 and PC-3 cell lines, in particular compound 118 (Figure 17) with the value of $\log \mathrm{IC}_{50}=0.42$ and $0.67 \mu \mathrm{M}$, respectively [108].<smiles>O=C(/C=C/c1ccco1)c1cc2cc(Br)ccc2o1</smiles><smiles>Cc1c(C(=O)c2ccccc2)oc2cc(OCCN3CCOCC3)ccc12</smiles><smiles>[R12]C(=O)Nc1ccc(C(=O)O)cc1</smiles>
121<smiles>[R]c1ccc2oc(NC(=O)Nc3ccc(C)c(S(N)(=O)=O)c3)c([R])c2c1</smiles>

124a-b $\mathrm{NH}_{2}$

124a: $\mathrm{R}=\mathrm{H}, \mathrm{R}_{1}=\mathrm{CH}_{3}$; 124b: $\mathrm{R}=\mathrm{Br}, \mathrm{R}_{1}=\mathrm{H}$

125<smiles>Cc1c(NC(=O)Nc2cccc(C(=O)O)c2)oc2ccccc12</smiles><smiles>O=C(Nc1cccc(C(=O)O)c1)Nc1cc2cc(Br)ccc2o1</smiles><smiles>[R]c1ccc2oc(NC(=O)Nc3ccc(S(N)(=O)=O)cc3)c([R7])c2c1</smiles><smiles>[R]c1ccc2c(c1)/C(=N/NC(=O)c1cc3cc(Br)ccc3o1)C(=O)N2[R2]</smiles><smiles>[R]c1ccc2c(c1)/C(=N/NC(=O)c1cc3cc(Br)ccc3o1)C(=O)N2</smiles>

a: $\mathrm{R}=\mathrm{Br} ; \mathbf{b}: \mathrm{R}=\mathrm{OCH}_{3}$

Figure 17. Benzofuran derivatives as anti-breast cancer agents.

It is also reported that a novel series of benzofuran derivatives was designed and synthesized as potential oestrogen receptor inhibitors endowed with anti-breast cancer activity. Among these compounds, 2-benzoyl-3-methyl-6-[2-(morpholin-4-yl)ethoxy] benzofuran (119) (Figure 17) owned the most potent activity against MCF-7 human breast cancer cells with inhibitory percentage of $64.23 \%$ at $50 \mu \mathrm{M}$ and showed a low toxicity toward normal cells. Moreover, a comprehensive structure-activity relationship was extracted from this study [109].

In 2020, Eldehna et al. reported the design and synthesis for new 2-methylbenzofuran $\mathbf{1 2 0}$ or 5-bromobenzofuran $\mathbf{1 2 1}$ derivatives featuring the carboxylic acid functionality represented in the benzoic and hippuric acid moieties (Figure 17). The target 2-methylbenzofuran or 5-bromobenzofuran derivatives were assessed for their inhibitory action against cancerrelated human carbonic anhydrases ( $h$ CA) IX and XII isoforms. They displayed good inhibitory activity and selectivity toward $h$ CA IX isoform ( $K_{\mathrm{I}}$ s ranging from 0.56 to $\left.5.1 \mu \mathrm{M}\right)$, and subsequently the most potent inhibitors were screened for their potential antitumor 
impact against two human breast cancer cell lines, MCF-7 and MDA-MB-231. In particular, 5-bromobenzofuran-based counterpart 122 exerted the best anti-proliferative action against the examined TNBC MDA-MB-231 cells $\left(\mathrm{IC}_{50}=2.52 \pm 0.39 \mu \mathrm{M}\right)$ which was comparable to doxorubicin $\left(\mathrm{IC}_{50}=2.36 \pm 0.18 \mu \mathrm{M}\right)$. Moreover, compound 122 significantly elevated (from 0.78 to $31.88 \%$ ) the Annexin V-FITC positive MDA-MB-231 apoptotic cells, as well as led to a cell cycle disturbance through alteration of $S u b-G_{1}$ phase and arrest of $G_{2}-M$ stage (Figure 17) [110].

One year later, in 2021, novel sets of ureido benzofurans incorporating sulfonamide functionality (123, Figure 17) were developed as anti-breast cancer agents targeting cancerrelated $h$ CA IX and XII isoforms. Several derivatives potently inhibited the cancer-related $h$ CA IX isoform within the single-digit nanomolar range $\left(K_{\mathrm{I}} \mathrm{s}: 1.8-8.4 \mathrm{nM}\right)$. Further MTT assay was performed, which ascribed potent anti-proliferative impact to 124a against BC MCF-7 cells $\left(\mathrm{IC}_{50}=6.45 \mu \mathrm{M}\right)$ and MDA-MB-231 cells $\left(\mathrm{IC}_{50}=6.27 \mu \mathrm{M}\right)$, whereas $124 \mathrm{~b}$ exhibited moderate activity toward BC MCF-7 cells $\left(\mathrm{IC}_{50}=13.79 \mu \mathrm{M}\right)$ and MDA-MB-231 cells $\left(\mathrm{IC}_{50}=14.16 \mu \mathrm{M}\right)$. Further investigations revealed that treatment of BC MCF-7 and MDA-MB-231 cells with ureido benzofuran 124a led to up-regulation of the expression levels of pro-apoptotic Bax and Caspase-3 proteins, and down-regulation for anti-apoptotic Bcl-2 protein expression level (Figure 17) [111].

Additionally in 2021, the design and synthesis of novel sets of 5-bromobenzofuranbased small molecules tethered with indolin-2-one (125, Figure 17) moiety were described by Eldehna et al. [112]. The target benzofuran-indolinone conjugates were developed as dual inhibitors for the two key oncotargets CDK2/GSK-3 $\beta$ that are involved in breast cancer. All the reported benzofuran-indolinone conjugates in this study were screened for their anti-breast cancer activity towards T-47D and MCF-7 cell lines. Superiorly, conjugates incorporating $N^{1}$-unsubstituted indolinone moieties exerted moderate to potent activity toward both T-47D ( $\left.\mathrm{IC}_{50}: 1.27 \pm 0.04-9.67 \pm 0.31 \mu \mathrm{M}\right)$ and MCF-7 (IC 50 : $2.27 \pm 0.06-12.93 \pm 0.38 \mu \mathrm{M})$ cell lines. Moreover, a CDK2 and GSK-3 $\beta$ enzyme inhibition assay, for conjugates incorporating $N^{1}$-unsubstituted indolinone moieties, identified benzofuran-based conjugates $\mathbf{1 2 6} \mathbf{a}-\mathbf{b}$ (Figure 17) as potent dual CDK2/GSK-3 $\beta$ inhibitors with $\mathrm{IC}_{50}$ values equal to 37.77 and $52.75 \mathrm{nM}$, respectively, toward $\mathrm{CDK} 2$, and $\mathrm{IC}_{50}$ values equal to 32.09 and $40.13 \mathrm{nM}$, respectively, toward GSK-3 $\beta$.

\section{Miscellaneous Anti-Breast Cancer Agents}

A new series of thirty-three combretastatin A-4 (CA-4) analogs conjugated to piperazine moiety was synthesized via Perkin reaction by Boyle et al. in 2019 [113] and tested against MCF-7 breast cancer cells. Compounds 127a-c (Figure 18) showed potent antiproliferative activity against MCF-7 cells with a range of $\mathrm{IC}_{50}: 83-190 \mathrm{nM}$, as well as induced apoptosis via arresting cell cycle G2/M phase in MCF-7 cancer cell line. Moreover, the developed CA-4 analogs were able to act directly on tubulin as microtubule-destabilizing agents. Moreover, another research group developed a novel series of cyclohexyl thiosemicarbazone derivatives to screen their cytotoxic activity. Compound $\mathbf{1 2 8}$ (Figure 18) displayed the highest activity against three breast cancer cell lines: MDA-MB-468, MDA-MB-231 and $\mathrm{SKBr}-3$, with a range of $\mathrm{IC}_{50}$ values of 24.50 $\pm 0.01-32.2 \pm 0.09 \mu \mathrm{M}$. Unfortunately, the aforementioned compounds did not show any activity against breast cancer MCF-7 cell lines [114].

In 2014, Weldon et al. synthesized a series of cinnamylidene acetophenones and studied their anticancer activity. The results indicated that compounds $\mathbf{1 2 9} \mathbf{a}-\mathbf{b}$ (Figure 18) displayed sub-micromolar activity toward MDA-MB-468 and MCF-7 cells with relatively less activity against normal cell MCF-10A cells [115]. In addition, Varela and coworkers synthesized three metabolites of the steroidal aromatase inhibitor exemestane and tested them against MCF-7aro cells. Steroid 130 (Figure 18) displayed the most potent inhibition of MCF-7aro cells viability with $\mathrm{IC}_{50}$ of $0.25 \mu \mathrm{M}$. In addition, it induces loss of plasma membrane integrity [116]. 
<smiles>[R]c1ccc(C=O)cc1[R]</smiles><smiles>[R9]N1CCNCC1</smiles>

Reagents and conditions: (i) TEA, $A c_{2} \mathrm{O}$, reflux, $4 \mathrm{~h}, 40-51 \%$;

(ii) $\mathrm{TEA}, \mathrm{Ac}_{2} \mathrm{O}, 120^{\circ} \mathrm{C}, 30 \mathrm{~min}$, microwaves, 36-83\%,

(iii) DCC, $\mathrm{HOBt}, \mathrm{DMF}$, anhydrous $\mathrm{CH}_{2} \mathrm{Cl}_{2}, 30$ min then overnight, rt, 4-32\% (iv) 2-Chloro-1-methylpyridinium iodide, anhydrous $\mathrm{CH}_{2} \mathrm{Cl}_{2}, \mathrm{rt}, 5 \mathrm{~min}$, then piperazine, triethylamine, $\mathrm{rt}, 1 \mathrm{~h}, 1-88 \%$;

a, $\mathrm{R}_{1}=\mathrm{OH}, \mathrm{R}_{2}=\mathrm{OCH}_{3}, \mathrm{R}_{3}=\mathrm{C}_{6} \mathrm{H}_{5}$<smiles>[R2]c1ccc(/C=C(/C(=O)N2CCN([R])CC2)c2cc(OC)c(OC)c(OC)c2)cc1[R]</smiles>

c, $\mathrm{R}_{1}=\mathrm{NH}_{2}, \mathrm{R}_{2}=\mathrm{OCH}_{3}, \mathrm{R}_{3}=\mathrm{C}_{6} \mathrm{H}_{4}\left(\mathrm{CH}_{3}\right) p$<smiles>COC1=CC(=NNC(=S)NC2CCCCC2)CC=C1</smiles>

128<smiles>[R]C(=O)/C=C\C=C\c1ccccc1[N+](=O)[O-]</smiles>

129a, R =Furyl; 129b, R =Phenyl<smiles>C=C1C[C@H]2[C@H]3CCC(=O)[C@@]3(C)CC[C@H]2[C@]2(C)C1=CC(=O)[C@@H]1O[C@@H]12</smiles><smiles>C1=C(c2ccc(OCCN3CCCCC3)cc2)c2ccccc2Sc2ccccc21</smiles>

131<smiles>C[C@]12C=CC(=O)C=C1CCC1C2CC[C@](C)(CC#N)C1CC#N</smiles>

132

Figure 18. Miscellaneous compounds as anti-breast cancer agents.

Ansari et al. [117] synthesized two series of dibenzo[b,f]thiepines and dibenzo[b,f]oxepines, and then tested their anticancer activity against breast cancer (MDA-MB-231 and MCF-7) cell lines. Assay results displayed that compound 131 (Figure 18) exhibited the highest activity with $\mathrm{IC}_{50}$ values of $1.33 \mu \mathrm{M}$ for MCF-7 and $5 \mu \mathrm{M}$ for MDA-MB-231 with cell cycle arrest at G0/G1 phase in MCF-7. Moreover, compound 132 (Figure 18) revealed excellent anti-proliferative activity against breast cancer (MDA-MB-231 and MCF-7) cell lines with $\mathrm{IC}_{50}$ values $=0.11$ and $0.52 \mu \mathrm{M}$, respectively [118].

Furthermore, Kaur et al. developed a novel series of ospemifene analogs and tested their cytotoxic activity against MDA-MB-231 (ER-negative) and MCF-7 (ER-positive) cancer cell lines. The novel compounds 134 and 136 (Figure 19) were found to be more effective than the reference (ospemifene and tamoxifen) against MDA-MB-231 cells $\left(\mathrm{IC}_{50}=25\right.$ and $17.1 \mu \mathrm{M}$, respectively) and against MCF-7 cells ( $\mathrm{IC}_{50}=15.9$ and $23.6 \mu \mathrm{M}$, respectively). Moreover, compound 137 (Figure 19) showed potent cytotoxic activity against MCF-7 cells $\left(\mathrm{IC}_{50}=76 \mu \mathrm{M}\right)$ comparable to that of ospemifene and tamoxifen [119]. 

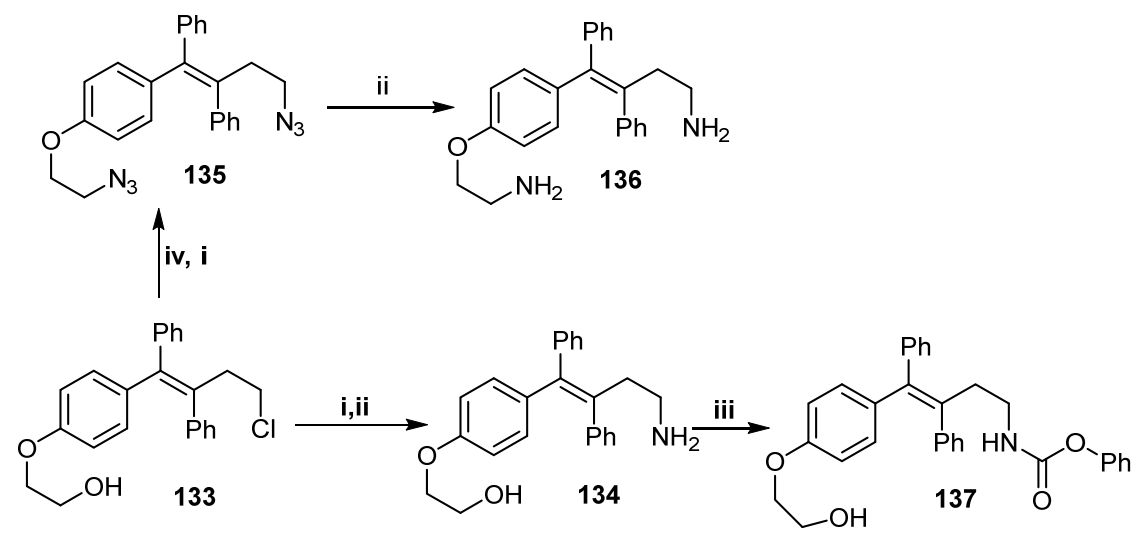

(i) $\mathrm{NaN}_{3}$, Dry DMF $80^{\circ} \mathrm{C}, 12 \mathrm{~h}$; (ii) $\mathrm{ZN}, \mathrm{NH}_{4} \mathrm{Cl}$, EtOH: $\mathrm{H}_{2} \mathrm{O}(8: 2)$,reflux, 8h, phenylchloroformate, (iii) $\mathrm{K}_{2} \mathrm{CO}_{3}$, Dry dioxane, RT, 2h; (iv) $\mathrm{Et}_{3} \mathrm{~N}, \mathrm{MeSO}_{2} \mathrm{Cl}$, Dry $\mathrm{CH}_{2} \mathrm{Cl}_{2}$, RT, 4h

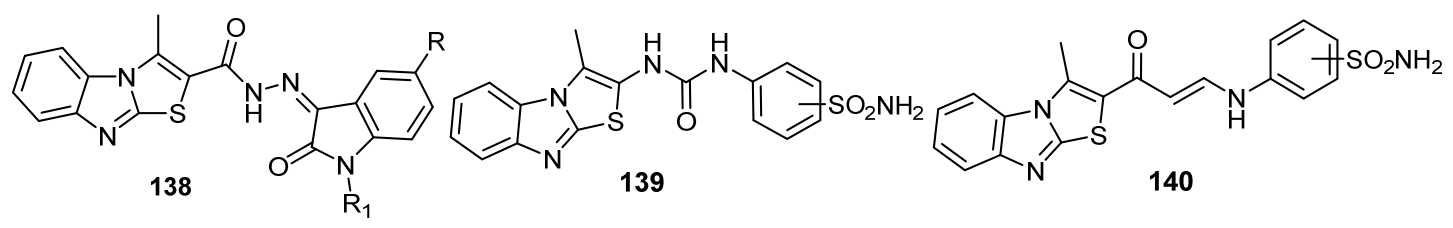

Figure 19. Miscellaneous compounds as anti-breast cancer agents.

Recently, Eldehna et al. reported two studies concerning development of novel thiazolo[3,2a]benzimidazole derivatives as antitumor agents against breast cancer cell lines. In the first study, the thiazolo[3,2-a]benzimidazole moiety was conjugated with different isatin motifs (138, Figure 19) to afford new CDK2 inhibitors ( $\left.\mathrm{IC}_{50}: 26.24 \pm 1.4-96.46 \pm 5.3 \mathrm{nM}\right)$ with potent activity against $\mathrm{BC}$ MCF-7 cell line $\left(\mathrm{IC}_{50}: 1.27 \pm 0.06-16.83 \pm 0.95 \mu \mathrm{M}\right)$ and against MDA-MB-231 cell line ( $\left.\mathrm{IC}_{50}: 2.60 \pm 1.47-20.90 \pm 1.17 \mu \mathrm{M}\right)$ [120]. The second study reported the conjugation of the thiazolo[3,2-a]benzimidazole framework with a benzenesulfonamide moiety through urea (139, Figure 19) or enaminone (140, Figure 19) linkers to furnish a novel class of potent and selective inhibitors of cancer-related $h$ CA IX and XII isoforms with inhibition constants in the nanomolar range. The most potent $C A$ inhibitors displayed further efficient cell growth inhibitory activity against BC MCF-7 and MDA-MB-231 cell lines under both normoxic and hypoxic conditions. Further investigations revealed their impact on induction of apoptosis and cell cycle progression [121].

On the other hand, Lu et al. developed eight novel ferrocenyl derivatives and assessed their in vitro anti-proliferative activity. The results showed that most of the synthesized compounds displayed good activity, in particular compounds 141 and 142 (Figure 20) exerted the best activity against MCF-7 (IC $50=56$ and $47 \mu \mathrm{M}$, respectively) and MDA-MB$231\left(\mathrm{IC}_{50}=61\right.$ and $87 \mu \mathrm{M}$, respectively) cell lines [122].

In 2012, Tan et al. designed and synthesized a novel series of compounds formed by ferrocenyl group tethered to a catechol via a conjugated system. The compounds were assessed for their antitumor activity. Compound 143 (Figure 20) exhibited the highest anti-proliferative activity against the MDA-MB-231 cancer cell line with an $\mathrm{IC}_{50}$ value of $0.48 \pm 0.04 \mu \mathrm{M}$ [123]. Moreover, the Selective Estrogen Receptor Modulators (SERMs) bearing a ferrocenyl-oxabicyclo[2.2.1] heptenes were prepared and screened as anti-breast cancer agents. The results exhibited that compounds $144\left(\mathrm{IC}_{50}=3.1 \pm 0.5 \mu \mathrm{M}\right.$ for MCF-7) and $145\left(\mathrm{IC}_{50}=7.8 \pm 0.6 \mu \mathrm{M}\right.$ for MDA-MB-231) (Figure 20) were the most potent antiproliferative agents against MCF-7 and MDA-MB-231 cancer cell lines [124].

Marinero and coworkers synthesized new derivatives of ferrocenyl compounds and evaluated their anticancer activity against TNBC MDA-MB-231 and MCF-7 cell lines. All these compounds displayed high antitumor activity with $\mathrm{IC}_{50}$ values ranging between 0.5 and $4.12 \mu \mathrm{M}$. Compounds 146a and 146b (Figure 20) exhibited the most efficient antiproliferative activity toward the MDA-MB-231 cell line $\left(\mathrm{IC}_{50}=0.50 \mu \mathrm{M}\right.$ and $0.54 \mu \mathrm{M}$, 
respectively), whereas 146c (Figure 20) elicited the most potent activity against MCF-7 cells [125]. Furthermore, a novel class of indeno[1,2-c]isoquinolines bearing the ferrocenyl scaffold was synthesized. The most potent compound, 147, (Figure 20) revealed the highest activity toward MDA-MB-231 breast cancer cell line compared to the reference drug etoposide [126].

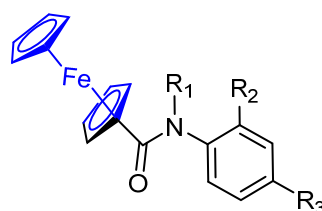

141; $\mathrm{R}_{1}=\mathrm{Ph}, \mathrm{R}_{2}=\mathrm{CH}_{3}, \mathrm{R}_{3}=\mathrm{OCH}_{3}$ 141; $\mathrm{R}_{1}=\mathrm{Ph}, \mathrm{R}_{2}=\mathrm{CH}_{1}=4-\mathrm{OCH}_{3}-\mathrm{C}_{6} \mathrm{H}_{4}, \mathrm{R}_{2}=\mathrm{H}, \mathrm{R}_{3}=\mathrm{OCH}_{3}$<smiles>Oc1ccc(C(=C2CC3C=CC(CC3)C2C2CC2)c2ccccc2)cc1</smiles>
143<smiles>Oc1ccc(C2C3CCC(O3)C(c3ccc(Br)cc3)C2Oc2ccccc2)cc1</smiles>

144<smiles>Oc1ccc(C2=C(c3ccc(O)cc3)C(CCc3ccc(Cc4ccccc4)cc3)CC2)cc1</smiles><smiles>[R]c1ccc(C(=C(CC)C23C=CC2CCC3)c2ccccc2)cc1</smiles>

146a-c<smiles>[R][C@H](C)NC(=O)CCCCC(C)(C)N1C(=O)CCC1=O</smiles>

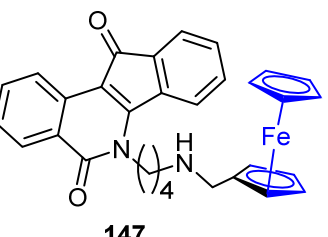

147

Figure 20. Miscellaneous compounds as anti-breast cancer agents.

Interestingly, organometallic complexes have taken reputation as effective and potent anticancer agents. Accordingly, three nano Ni(II) and $\mathrm{Cu}$ (II) complexes 148-150 (Figure 21) were synthesized via condensation reaction of 2-hydroxy-3-methoxybenzaldehyde with ethylamine or $\mathrm{N}, \mathrm{N}$-dimethyl-1,2-diaminoethane, followed by a complexation of the obtained Schiff base with $\mathrm{Cu}\left(\mathrm{NO}_{3}\right)_{2} \cdot 3 \mathrm{H}_{2} \mathrm{O}$ and $\mathrm{Ni}\left(\mathrm{NO}_{3}\right)_{2} \cdot 6 \mathrm{H}_{2} \mathrm{O}$. The new complexes' particle diameters were decreased using green manual grinding technology and the antiproliferative activity of the produced complexes was assessed against the MCF-7 cancer cell line. The results displayed that complex 148 (Figure 21) revealed significant anticancer activity against MCF-7 cancer by inducing apoptosis [127].

In addition, it was reported that three novel platinum(IV) complexes were synthesized and screened for their anticancer activity. Compound 151 (Figure 21) showed the highest cytotoxic activity against MDA-MB-231 $\left(\mathrm{IC}_{50}=68.023 \mu \mathrm{M}\right)$ with induction of apoptosis [128].

Furthermore, two complexes of platinum(II) dichloride were synthesized and investigated against two breast cancer cell lines, MCF-7 and MDA-MB-231. Compounds 152 and 153 (Figure 21) showed potent inhibition activity and induced apoptosis in a similar way to cisplatin on tested cells. They also revealed anti-migration activity of MDA-MB-231 cells by decreasing the levels of metabolic energy (ATP), distressing cytoskeletal organization membrane and cell polarity [129].

In 2020, Kutlu et al. [130] investigated some synthesized Ag(I)-NHC complexes, having a morpholinoethyl and benzimidazole for their in vitro anti-proliferative activity against MCF-7 and MDA-MB-231 human BC cell lines. Compound 154 (Figure 21) (IC 50 value of $17 \pm 1.41$ and $7.5 \pm 0.77 \mu \mathrm{M}$ against MCF-7 and MDA-MB-231 cell lines, respectively) displayed significant anti-proliferative activity, compared to cisplatin. 


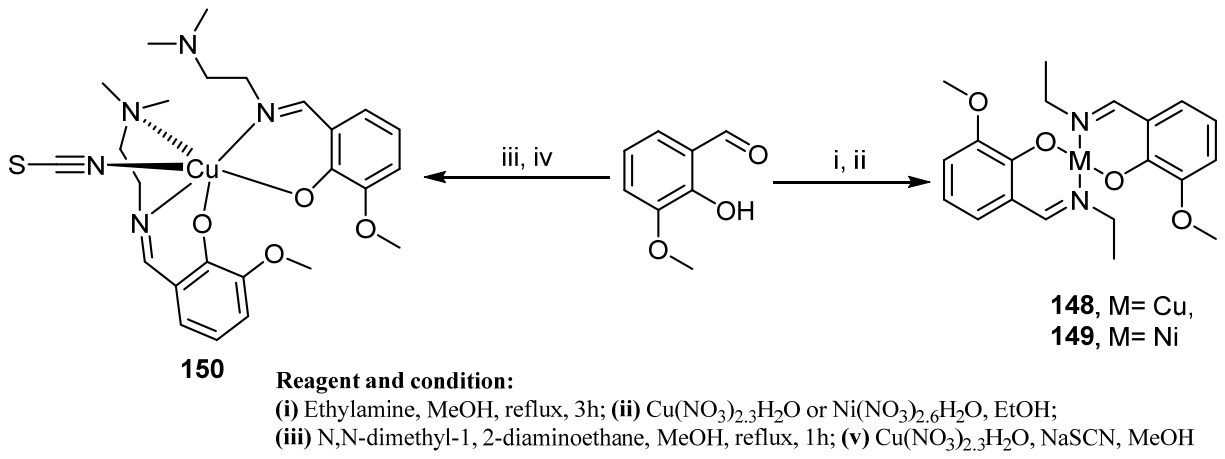<smiles>[R6]C(=O)C(C)N1CCN([C@@H](C)C([R6])=O)N(C)[P+]1(Cl)(Cl)(Cl)Cl</smiles><smiles></smiles>

152<smiles></smiles>

153<smiles>CC(C)N1c2ccccc2N(CCN2CCOCC2)C1C(=[Ga])C(C)(C)C</smiles>

154

Figure 21. Organometallic complexes as anti-breast cancer agents.

\section{Conclusions and Future Perspective}

Heading the list of critical health-associated problems worldwide, breast cancer stands as one of the most serious diseases responsible for a huge number of cancer-related mortality among women. Accordingly, development of novel efficient agents for management of the human breast malignancies is an urgent necessity. In this regard, considerable progress in the field of drug design and medicinal chemistry has been achieved, and several synthetic small molecules based on diversified chemical scaffolds have been identified as promising anti-breast cancer agents. This review summarized the recently reported different categories exploited to develop the synthetic anti-breast cancer candidates. To name just a few: quinoline, quinazoline, pyridine, pyridazine, pyrimidines, imidazole, benzimidazole, coumarin, tetrazole, indole, oxindole and triazine scaffolds were discussed in this review article. Moreover, the significant structure activity relationships, bioactivities and mechanistic insights for the reported small molecules were further concluded. It is worth stressing that surveying literature disclosed that there is a shortage in addressing invasion, migration and metastasis of BC, which reflects a discrepancy between the need and the assays for most of the reported anticancer agents. The present review article is expected to be contributory for the drug discovery community to support the future design and development of more potent, safer and selective candidates for breast cancer therapy.

Author Contributions: All the authors contributed equally in this work. All authors have read and agreed to the published version of the manuscript.

Funding: This research received no external funding.

Institutional Review Board Statement: Not applicable.

Informed Consent Statement: Not applicable.

Conflicts of Interest: The authors declare no conflict of interest. 


\section{References}

1. Torre, L.A.; Islami, F.; Siegel, R.L.; Ward, E.M.; Jemal, A. Global cancer in women: Burden and trends. Cancer Epidemiol. Prev. Biomark. 2017, 26, 444-457. [CrossRef] [PubMed]

2. ACS: American Cancer Society. Key Breast Cancer Statistics. Available online: https://cancerstatisticscenter.cancer.org/\#! / cancer-site/Breast/ (accessed on 24 August 2021).

3. Momenimovahed, Z.; Salehiniya, H. Epidemiological characteristics of and risk factors for breast cancer in the world. Breast Cancer Targets Ther. 2019, 11, 151-164. [CrossRef]

4. Lukong, K.E. Understanding breast cancer-The long and winding road. BBA Clin. 2017, 7, 64-77. [CrossRef]

5. Fedele, M.; Cerchia, L.; Chiappetta, G. The epithelial-to-mesenchymal transition in breast cancer: Focus on basal-like carcinomas. Cancers 2017, 9, 134. [CrossRef] [PubMed]

6. Jia, L.Y.; Shanmugam, M.K.; Sethi, G.; Bishayee, A. Potential role of targeted therapies in the treatment of triple-negative breast cancer. Anticancer Drugs 2016, 27, 147-155. [CrossRef] [PubMed]

7. Wang, C.; Kar, S.; Lai, X.; Cai, W.; Arfuso, F.; Sethi, G.; Lobie, P.E.; Goh, B.C.; Lim, L.H.; Hartman, M.J. Triple negative breast cancer in Asia: An insider's view. Cancer Treat. Rev. 2018, 62, 29-38. [CrossRef] [PubMed]

8. Alvarez, R.H.; Valero, V.; Hortobagyi, G.N. Emerging targeted therapies for breast cancer. J. Clin. Oncol. 2010, $28,3366-3379$. [CrossRef]

9. Perez, E.A.; Spano, J.P. Current and emerging targeted therapies for metastatic breast cancer. Cancer 2012, 118, 3014-3025. [CrossRef]

10. Sharma, D.; Kumar, S.; Narasimhan, B. Estrogen alpha receptor antagonists for the treatment of breast cancer: A review. Chem. Cent. J. 2018, 12, 107. [CrossRef]

11. Liu, J.; Ming, B.; Gong, G.H.; Wang, D.; Bao, G.L.; Yu, L.J. Current research on anti-breast cancer synthetic compounds. RSC Adv. 2018, 8, 4386-4416. [CrossRef]

12. Mostafa, A.S.; Gomaa, R.M.; Elmorsy, M.A. Design and synthesis of 2-phenyl benzimidazole derivatives as VEGFR-2 inhibitors with anti-breast cancer activity. Chem. Biol. Drug. Des. 2019, 93, 454-463. [CrossRef]

13. Branowska, D.; Ławecka, J.; Sobiczewski, M.; Karczmarzyk, Z.; Wysocki, W.; Wolińska, E.; Olender, E.; Mirosław, B.; Perzyna, A.; Bielawska, A.; et al. Synthesis of unsymmetrical disulfanes bearing 1,2,4-triazine scaffold and their in vitro screening towards anti-breast cancer activity. Mon. Chem.-Chem. Mon. 2018, 149, 1409-1420. [CrossRef]

14. Al-Warhi, T.; Sabt, A.; Elkaeed, E.B.; Eldehna, W.M. Recent advancements of coumarin-based anticancer agents: An up-to-date review. Bioorg. Chem. 2020, 103, 104163. [CrossRef] [PubMed]

15. Fragomeni, S.M.; Sciallis, A.; Jeruss, J.S. Molecular subtypes and local-regional control of breast cancer. Surg. Oncol. Clin. N. Am. 2018, 27, 95-120. [CrossRef] [PubMed]

16. Lehmann, B.D.; Bauer, J.A.; Chen, X.; Sanders, M.E.; Chakravarthy, A.B.; Shyr, Y.; Pietenpol, J.A. Identification of human triple-negative breast cancer subtypes and preclinical models for selection of targeted therapies. J. Clin. Investig. 2011, 121, 2750-2767. [CrossRef]

17. Mitra, S. MicroRNA therapeutics in triple negative breast cancer. Arch. Pathol. Clin. Res. 2017, 1, 9-17.

18. Moo, T.A.; Sanford, R.; Dang, C.; Morrow, M. Overview of breast cancer therapy. PET Clin. 2018, 13, 339-354. [CrossRef] [PubMed]

19. Maughan, K.L.; Lutterbie, M.A.; Ham, P.S. Treatment of breast cancer. Chemotherapy 2010, 81, 1339-1346.

20. Nicholls, L.; Gorayski, P.; Harvey, J. Osteoradionecrosis of the ribs following breast radiotherapy. Case Rep. Oncol. 2015, 8, 332-338. [CrossRef]

21. Dallavalle, S.; Dobričić, V.; Lazzarato, L.; Gazzano, E.; Machuqueiro, M.; Pajeva, I.; Tsakovska, I.; Zidar, N.; Fruttero, R. Improvement of conventional anti-cancer drugs as new tools against multidrug resistant tumors. Drug Resist. Updates 2020, 50, 100682. [CrossRef]

22. Choi, Y.H.; Yu, A. ABC transporters in multidrug resistance and pharmacokinetics, and strategies for drug development. Curr. Pharm. Des. 2014, 20, 793-807. [CrossRef]

23. Rivera, E. Implications of anthracycline-resistant and taxane resistant metastatic breast cancer and new therapeutic options. Breast J. 2010, 16, 252-263. [CrossRef]

24. Perez, I.E.; Alam, S.T.; Hernandez, G.A. Cancer therapy-related cardiac dysfunction: An overview for the clinician. Clin Med. Insights Cardiol. 2019, 13, 1-11. [CrossRef] [PubMed]

25. Jiang, Z.; Yang, Y.; Li, L.; Yue, Z.; Lan, L.; Pan, Z. Capecitabine monotherapy in advanced breast cancer resistant to anthracycline and taxane: A meta-analysis. J. Cancer Res. Ther. 2018, 14, 957-963. [CrossRef]

26. Bryer, E.; Henry, D. Chemotherapy-induced anemia: Etiology, pathophysiology, and implications for contemporary practice. Int. J. Clin. Transfus. Med. 2018, 6, 21-31. [CrossRef]

27. Nurgali, K.; Jagoe, R.T.; Abalo, R. Editorial: Adverse effects of cancer chemotherapy: Anything new to improve tolerance and reduce sequelae? Front. Pharmacol. 2018, 9, 245. [CrossRef]

28. Pedersini, R.A.; Vassalli, L.A.; Claps, M.B.; Tulla, A.B.; Rodella, F.B.; Grisanti, S.B.; Amoroso, V.B.; Roca, E.B.; Simoncini, E.L.C.; Berruti, A.B. Eribulin in heavily pretreated metastatic breast cancer patients in the real world: A retrospective study. Oncology 2018, 94 (Suppl. S1), 10-15. [CrossRef]

29. Houghton, P.J. Everolimus. Clin. Cancer Res. 2010, 16, 1368-1372. [CrossRef] [PubMed]

30. Zureick, A.H.; McFadden, K.A.; Mody, R.; Koschmann, C. Successful treatment of a TSC2-mutant glioblastoma with everolimus. BMJ Case Rep. CP 2019, 31, e227734. [CrossRef] [PubMed] 
31. Peri, M.; Fazio, N. Clinical evaluation of everolimus in the treatment of neuroendocrine tumors of the lung: Patient selection and special considerations. A systematic and critical review of the literature. Lung Cancer Targets Ther. 2020, 11, 41-52. [CrossRef]

32. Nasrazadani, A.; Brufsky, A. Neratinib: The emergence of a new player in the management of HER2+ breast cancer brain metastasis. Future Oncol. 2020, 16, 247-254. [CrossRef]

33. Liu, M.; Liu, H.; Chen, J. Mechanisms of the CDK4/6 inhibitor palbociclib (PD 0332991) and its future application in cancer treatment (Review). Oncol. Rep. 2018, 39, 901-911. [CrossRef]

34. Hortobagyi, G.N. Ribociclib for the first-line treatment of advanced hormone receptor-positive breast cancer: A review of subgroup analyses from the MONALEESA-2 trial. Breast Cancer Res. 2018, 20, 123. [PubMed]

35. Kulukian, A.; Lee, P.; Taylor, J.; Rosler, R.; de Vries, P.; Watson, D.; Forero-Torres, A.; Peterson, S. Preclinical activity of HER2selective tyrosine kinase inhibitor tucatinib as a single agent or in combination with trastuzumab or docetaxel in solid tumor models. Mol. Cancer Ther. 2020, 19, 976-987. [CrossRef] [PubMed]

36. Gobbi, S.; Rampa, A.; Belluti, F.; Bisi, A. Nonsteroidal aromatase inhibitors for the treatment of breast cancer: An update. Anticancer Agents Med. Chem. 2014, 14, 54-65. [CrossRef]

37. Dumontet, C.; Jordan, M.A.; Lee, F.F.Y. Ixabepilone: Targeting $\beta$ III-tubulin expression in taxane-resistant malignancies. Mol. Cancer Ther. 2009, 8, 17-25. [CrossRef]

38. Bergh, J.; Jonsson, P.E.; Lidbrink, E.K.; Trudeau, M.; Eiermann, W.; Brattstrom, D.; Lindeman, J.P.O.; Wiklund, F.; Henriksson, R. FACT: An open-label randomized phase III study of fulvestrant and anastrozole in combination compared with anastrozole alone as first-line therapy for patients with receptor-positive postmenopausal breast cancer. J. Clin. Oncol. 2012, 30, 1919-1925.

39. Sardesai, S.D.; Storniolo, A.M. Lapatinib: An oral dual tyrosine kinase inhibitor for HER-2-positive breast cancer. Womens Health 2015, 11, 281-294. [CrossRef]

40. Smith, M.B.; Reardon, J.; Olson, E.M. Pertuzumab for the treatment of patients with previously untreated her2-positive metastatic breast cancer. Drugs Today 2012, 48, 713-722.

41. André, F.; Ciruelos, E.; Rubovszky, G.; Campone, M.; Loibl, S.; Rugo, H.S.; Iwata, H.; Conte, P.; Mayer, I.A.; Kaufamn, B.; et al. For the SOLAR-1 study group. Alpelisib for PIK3CA-mutated, hormone receptor-positive advanced breast cancer. N. Engl. J. Med. 2019, 380, 1929-1940. [CrossRef] [PubMed]

42. Exman, P.; Barroso-Sousa, R.; Tolaney, S.M. Evidence to date: Talazoparib in the treatment of breast cancer. OncoTargets Ther. 2019, 12, 5177-5187. [CrossRef]

43. Viswas, R.S.; Pundir, S.; Lee, H. Design and synthesis of 4-piperazinyl quinoline derived urea/thioureas for anti-breast cancer activity by a hybrid pharmacophore approach. J. Enzyme Inhib. Med. Chem. 2019, 34, 620-630. [CrossRef] [PubMed]

44. Zarghi, A.; Ghodsi, R.; Azizi, E. Design, synthesis and biological evaluation of 4-(imidazolylmethyl)-2-(4-methylsulfonyl Phenyl)quinoline derivatives as selective COX-2 inhibitors and in-vitro anti-breast cancer agents. Iran. J. Pharm. Res. 2016, 15, 169-177.

45. Bheemanapalli, L.N.; Kaur, A.; Arora, R.; Akkinepally, R.R.; Javali, N.M. Synthesis, evaluation of 6,8-dibromo-2-aryl-2,3dihydroquinolin-4(1H)-ones in MCF-7 (breast cancer) cell lines and their docking studies. Med. Chem. Res. 2012, 21, 1741-1750. [CrossRef]

46. Mohammadhosseini, N.; Pordeli, M.; Safavi, M.; Firoozpour, L.; Amin, F.; Ardestani, S.K.; Edraki, N.; Shafee, A.; Foroumadi, A. Novel N-2-(furyl)-2-(chlorobenzyloxyimino) ethyl piperazinyl quinolones: Synthesis, cytotoxic evaluation and structure-activity relationship. Iran. J. Pharm. Res. 2015, 14, 1095-1103.

47. Moustafa, A.M.Y.; Bakare, S.B. Synthesis of some hybrid 7-hydroxy quinolinone derivatives as anti breast cancer drugs. Res. Chem. Intermed. 2019, 45, 3895-3912. [CrossRef]

48. Patel, K.S.; Rathi, J.C.; Dhiman, N. Design, synthesis and molecular modeling of new quinoline analogues as potential anti-cancer agents. Mater. Today Proc. 2020, 28, 77-84. [CrossRef]

49. Yin, S.; Tang, C.; Wang, B.; Zhang, Y.; Zhou, L.; Xue, L.; Zhang, C. Design, synthesis and biological evaluation of novel EGFR/HER2 dual inhibitors bearing a oxazolo[4,5-g]quinazolin-2(1H)-one scaffold. Eur. J. Med. Chem. 2016, 120, 26-36. [CrossRef]

50. Ahmed, M.F.; Belal, A.; Youns, M. Design, synthesis, molecular modeling and anti-breast cancer activity of novel quinazolin-4-one derivatives linked to thiazolidinone, oxadiazole or pyrazole moieties. Med. Chem. Res. 2015, 24, 2993-3007. [CrossRef]

51. Ahmed, M.F.; Hashim, A.A. Design, synthesis of novel quinazolin-4-one derivatives and biological evaluation against human MCF-7 breast cancer cell line. Res. Chem. Intermed. 2016, 42, 1777-1789. [CrossRef]

52. Faraj, F.L.; Zahedifard, M.; Paydar, M.; Looi, C.Y.; Majid, N.A.; Ali, H.M.; Ahmad, N.; Gwaram, N.S.; Abdulla, M.A. Synthesis, characterization, and anticancer activity of new quinazoline derivatives against MCF-7 cells. J. Sci. World 2014, 2014, 212096.

53. Wang, S.; Zhang, Y.; Ren, T.; Wu, Q.; Lu, H.; Qin, X.; Liu, Y.; Ding, H.; Zhao, Q. A novel 4-aminoquinazoline derivative, DHW-208, suppresses the growth of human breast cancer cells by targeting the PI3K/AKT/mTOR pathway. Cell Death Dis. 2020, 11, 491. [CrossRef] [PubMed]

54. Khalili, F.; Akrami, S.; Safavi, M.; Mohammadi-Khanaposhtani, M.; Saeedi, M.; Ardestani, S.K.; Larijani, B.; Zonouzi, A.; Tehrani, M.B.; Mahdavi, M. Design, synthesis, in vitro cytotoxic activity evaluation, and study of apoptosis inducing effect of new styrylimidazo[1,2-a]pyridines as potent anti-breast cancer agents. Anti-Cancer Agents Med. Chem. 2019, 19, 265-275. [CrossRef]

55. Pang, C.; Sun, C.; Wang, J.; Xiao, D.; Ding, L.; Bu, H. Novel 2H-pyrazolo[4,3-c]hexahydropyridine derivatives: Synthesis, crystal structure, fluorescence properties and cytotoxicity evaluation against human breast cancer cells. Sci. China Chem. 2013, 56, 702-715. 
56. Prasad, S.S.; Kumar, K.S.; Jayaprakash, S.H.; Krishna, B.S.; Sundar, C.S.; Rao, P.V.; Babu, T.M.; Rajendra, W.; Reddy, S.C. Design, synthesis, antioxidant, and anti-breast cancer Activities of novel diethyl (alkyl/aryl/ heteroarylamino)(4-(pyridine-2yl)phenyl)methylphosphonates. Arch. Pharm. 2013, 346, 380-391.

57. Rahnamay, M.; Mahdavi, M.; Shekarchi, A.A.; Zare, P.; Feizi, M.A.H. Cytotoxic and apoptosis inducing effect of some pyrano [3, 2-c] pyridine derivatives against MCF-7 breast cancer cells. Acta Biochim. Pol. 2018, 65, 397-402. [CrossRef]

58. Sabt, A.; Eldehna, W.M.; Al-Warhi, T.; Alotaibi, O.J.; Elaasser, M.M.; Suliman, H.; Abdel-Aziz, H.A. Discovery of 3,6-disubstituted pyridazines as a novel class of anticancer agents targeting cyclin-dependent kinase 2: Synthesis, biological evaluation and in silico insights. J. Enzyme Inhib. Med. Chem. 2020, 35, 1616-1630. [CrossRef]

59. Kim, C.; Park, E.H.; Park, M.S. Novel alkylaminopyridazine derivatives: Synthesis and their anti-proliferative effects against MCF-7 cells. Bull. Korean Chem. Soc. 2013, 34, 3317-3321.

60. Kim, C.; Kim, S.B.; Park, M.-S. Synthesis of novel 3-allylseleno-6 alkylthiopyridazines:their anticancer activity against MCF-7 cells. Arch. Pharm. Res. 2014, 37, 452-458.

61. Sengmany, S.; Sitter, M.; Léonel, E.; Gall, E.L.; Loirand, G.; Martens, T.; Dubreuil, D.; Dilasser, F.; Rousselle, M.; Sauzeau, V.; et al. Synthesis and biological evaluation of 3-amino-, 3-alkoxy- and 3-aryloxy-6-(hetero)arylpyridazines as potent antitumor agents. Bioorg. Med. Chem. Lett. 2019, 29, 755-760. [CrossRef]

62. Kolawole, O.A.; Banjo, S. In vitro biological estimation of 1,2,3-triazolo[4,5-d]pyrimidine derivatives as anti-breast cancer agent: DFT, QSAR and docking studies. Curr. Pharm. Biotechnol. 2020, 21, 70-78. [CrossRef]

63. Amr, A.E.E.; Ibrahimd, A.A.; El-Shehry, M.F.; Hosni, H.M.; Fayed, A.A.; Elsayed, E.A. In vitro and in vivo anti-breast cancer activities of some newly synthesized 5-(thiophen-2-yl)thieno-[2,3-d]pyrimidin-4-one candidates. Molecules 2019, $24,2255$. [CrossRef] [PubMed]

64. Ma, C.; Wang, Y.; Dong, F.; Wang, Z.; Zhao, Y.; Shan, Y.; Gu, W.; Wang, S. Synthesis and antitumor activity of isolongifoleno[7,8-d] thiazolo[3,2-a] pyrimidine derivatives via enhancing ROS level. Chem. Biol. Drug Des. 2019, 94, 1457-1466. [CrossRef]

65. Zhang, Y.; Wang, Y.; Zhao, Y.; Gu, W.; Zhu, Y.; Wang, S. Novel camphor-based pyrimidine derivatives induced cancer cell death through a ROS-mediated mitochondrial apoptosis pathway. RSC Adv. 2019, 9, 29711-29720. [CrossRef]

66. Zhang, C.H.; Zheng, M.W.; Li, Y.P.; Lin, X.D.; Huang, M.; Zhong, L.; Li, G.B.; Zhang, R.J.; Lin, W.T.; Jiao, Y.; et al. Design, synthesis, and structure-activity relationship studies of 3-(phenylethynyl)-1 $H$-pyrazolo[3,4-d]pyrimidin-4-amine derivatives as a new class of Srcinhibitors with potent activities in models of triple negative breast cancer. J. Med. Chem. 2015, 58, 3957-3974. [CrossRef]

67. Abd El-Salam, H.A.; Yakout, E.S.M.; El-Hashash, M.A.; Nawwar, G.A. Facile synthesis of 6-(heptadec-8-enyl) thiopyrimidines incorporating glycosyl moiety and their antitumor activity. Mon. Chem. 2013, 144, 1893-1901. [CrossRef]

68. Sharaky, M.; Kamel, M.; Aziz, M.A.; Omran, M.; Rageh, M.M.; Abouzid, K.A.M.; Shouman, S.A. Design, synthesis and biological evaluation of a new thieno[2,3-d]pyrimidinebased urea derivative with potential antitumor activity against tamoxifen sensitive and resistant breast cancer cell lines. J. Enzyme Inhib. Med. Chem. 2020, 35, 1641-1656. [CrossRef]

69. Meenakshisundaram, S.; Manickam, M.; Pillaiyar, T. Exploration of imidazole and imidazopyridine dimers as anticancer agents: Design, synthesis, and structure-activityrelationship study. Arch. Pharm. Chem. Life Sci. 2019, 352, 1900011. [CrossRef] [PubMed]

70. Yavuz, S.C.; Akkoc, S.; Sarıpınar, E. The cytotoxic activities of imidazole derivatives preparedfrom various guanylhydrazone and phenylglyoxalmonohydrate. Synth. Commun. 2019, 49, 3198-3209. [CrossRef]

71. Yadav, S.; Lim, S.M.; Ramasamy, K.; Vasudevan, M.; Shah SA, A.; Mathur, A.; Narasimhan, B. Synthesis and evaluation of antimicrobial, antitubercular and anticancer activities of 2-(1-benzoyl-1H-benzo[d]imidazol-2-ylthio)- $N$-substituted acetamides. Chem. Cent. J. 2018, 12, 66. [CrossRef]

72. Mohan, C.D.; Srinivasa, V.; Rangappa, S.; Mervin, L.; Mohan, S.; Paricharak, S.; Baday, S.; Li, F.; Shanmugam, M.K.; Chinnathambi, A.; et al. Trisubstituted-imidazoles induce apoptosis in human breast cancer cells by targeting the oncogenic PI3K/Akt/mTOR signaling pathway. PLoS ONE 2016, 11, e0153155. [CrossRef]

73. Kumar, S.; Saha, S.T.; Gu, L.; Palma, G.; Perumal, S.; Singh-Pillay, A.; Singh, P.; Anand, A.; Kaur, M.; Kumar, V. 1H 1,2,3-triazole tethered nitroimidazole-isatin conjugates: Synthesis, docking, and anti-proliferative evaluation against breast cancer. ACS Omega 2018, 3, 12106-12113. [CrossRef] [PubMed]

74. Karthikeyan, C.; Solomon, V.R.; Lee, H.; Trivedi, P. Synthesis and biological evaluation of 2-(phenyl)-3H-benzo[d]imidazole-5carboxylic acids and its methyl esters as potent anti-breast cancer agents. Arab. J. Chem. 2017, 10, S1788-S1794. [CrossRef]

75. Ahmed, E.Y.; Latif NA, A.; El-Mansy, M.F.; Elserwy, W.S.; Abdelhafez, O.M. VEGFR-2 inhibiting effect and molecular modeling of newly synthesized coumarin derivatives as anti-breast cancer agents. Bioorg. Med. Chem. 2020, 28, 115328. [CrossRef] [PubMed]

76. El-Samahy, F.A.; Abd El Salam, H.A.; El-Sayed, N.F.; Shalaby, E.M.; Dondeti, M.F. Synthesis of unexpected novel bis-coumarin derivatives via three component reactions of 4-hydroxycoumarin, aldehydes and cyclic secondary amines. Conformation in the solid state and pharmacological evaluation. Z. Nat. B 2017, 72, 705-716. [CrossRef]

77. Batran, R.B.; Dawood, D.H.; El-Seginy, S.A.; Ali, M.M.; Maher, T.J.; Gugnani, K.S.; Rondon-Ortiz, A.N. New coumarin derivatives as anti-breast and anti-cervical cancer agents targeting VEGFR-2 and p38aMAPK. Arch. Pharm. Chem. Life Sci. 2017, 350, e1700064. [CrossRef]

78. Sabt, A.; Abdelhafez, O.M.; El-Haggar, R.S.; Madkour, H.M.; Eldehna, W.M.; El-Khrisy, E.E.D.A.; Abdel-Rahman, M.A.; Rashed, L.A. Novel coumarin-6-sulfonamides as apoptotic anti-proliferative agents: Synthesis, in vitro biologicalevaluation, and QSAR studies. J. Enzyme Inhib. Med. Chem. 2018, 33, 1095-1107. [CrossRef] 
79. Dileep, K.; Polepalli, S.; Jain, N.; Buddana, S.K.; Prakasham, R.S.; Murty, M.S.R. Synthesis of novel tetrazole containing hybrid ciprofloxacin and pipemidic acid analogues and preliminary biological evaluation of their antibacterial and antiproliferative activity. Mol. Divers. 2018, 22, 83-93. [CrossRef]

80. Arshad, M.; Bhat, A.R.; Pokharel, S.; Kim, J.E.; Lee, E.J.; Athar, F.; Choi, I. Synthesis, characterization and anticancer screening of some novel piperonyl-tetrazole derivatives. Eur. J. Med. Chem. 2014, 71, 229-236. [CrossRef]

81. Kohler, S.C.; Wiese, M. HM30181 derivatives as novel $€$ potent and selective inhibitors of the breast cancer resistance protein (BCRP/ABCG2). J. Med. Chem. 2015, 58, 3910-3921. [CrossRef]

82. Sidhu, J.S.; Singla, R.; Jaitak, V. Indole derivatives as anticancer agents for breast cancer therapy: A review. Anti-Cancer Agents Med. Chem. 2016, 16, 160-173. [CrossRef]

83. Mady, M.S.; Mohyeldin, M.M.; Ebrahim, H.Y.; Elsayed, H.E.; Houssen, W.E.; Haggag, E.G.; Soliman, R.F.; El Sayed, K.A. The indole alkaloid meleagrin, from the olive tree endophytic fungus Penicillium chrysogenum, as a novel lead for the control of c-Met-dependent breast cancer proliferation, migration and invasion. Bioorg. Med. Chem. 2016, 24, 113-122. [CrossRef]

84. Guo, H.; Diao, Q.P. The anti-breast cancer potential of bis-isatin scaffolds. Curr. Top. Med. Chem. 2020, 20, 1499-1503. [CrossRef]

85. Eldehna, W.M.; Abo-Ashour, M.F.; Ibrahim, H.S.; Al-Ansary, G.H.; Ghabbour, H.A.; Elaasser, M.M.; Ahmedf, H.Y.A.; Safwat, N.A. Novel [(3-indolylmethylene)hydrazono]indolin-2-ones as apoptotic anti-proliferative agents: Design, synthesis and in vitro biological evaluation. J. Enzym. Inhib. Med. Chem. 2018, 33, 686-700. [CrossRef] [PubMed]

86. Kaur, H.; Singh, J.; Narasimhan, B. Indole hybridized diazenyl derivatives: Synthesis, antimicrobial activity, cytotoxicity evaluation and docking studies. BMC Chem. 2019, 13, 65. [CrossRef] [PubMed]

87. Gozzi, G.J.; Bouaziz, Z.; Winter, E.; Daflon-Yunes, N.; Aichele, D.; Nacereddine, A.; Marminon, C.; Valdameri, G.; Zeinyeh, W.; Bollacke, A.; et al. Converting potent indeno[1,2-b]indole inhibitors of protein kinase CK2 into selective inhibitors of the breast cancer resistance protein ABCG2. J. Med. Chem. 2014, 58, 265-277. [CrossRef]

88. Ma, J.; Bao, G.; Wang, L.; Li, W.; Xu, B.; Du, B.; Lv, J.; Zhai, X.; Gong, P. Design, synthesis, biological evaluation and preliminary mechanism study of novel benzothiazole derivatives bearing indole-based moiety as potent antitumor agents. Eur. J. Med. Chem. 2015, 96, 173-186. [CrossRef] [PubMed]

89. Li, X.; Zheng, S.L.; Li, X.; Li, J.L.; Qiang, O.; Liu, R.; He, L. Synthesis and anti-breast cancer activity of new indolylquinone derivatives. Eur. J. Med. Chem. 2012, 54, 42-48. [CrossRef]

90. Chakraborty, S.; Ghosh, S.; Banerjee, B.; Santra, A.; Adhikary, A.; Misra, A.K.; Sen, P.C. Phemindole, a synthetic di-indole derivative maneuvers the store operated calcium entry (SOCE) to induce potent anticarcinogenic activity in human triple negative breast cancer cells. Front. Pharmacol. 2016, 7, 114. [CrossRef]

91. Debnath, B.; Ganguly, S. Synthesis, biological evaluation, in silico docking, and virtual ADME studies of 2-[2-oxo-3-(arylimino)indolin1-yl]-N-arylacetamides as potent antibreast cancer agents. Mon. Chem.-Chem. Mon. 2016, 147, 565-574. [CrossRef]

92. Karthikeyan, C.; Solomon, V.R.; Lee, H.; Trivedi, P. Design, synthesis and biological evaluation of some isatin-linked chalcones as novel anti-breast cancer agents: A molecular hybridization approach. Biomed. Prev. Nutr. 2013, 3, 325-330. [CrossRef]

93. El-Faham, A.; Farooq, M.; Almarhoon, Z.; Alhameed, R.A.; Wadaan, M.A.M.; de la Torre, B.G.; Albericio, F. Di- and tri-substituted s-triazine derivatives: Synthesis, characterization, anticancer activity in human breast-cancer cell lines, and developmental toxicity in zebrafish embryos. Bioorg. Chem. 2019, 94, 103397. [CrossRef] [PubMed]

94. Srivastava, J.K.; Pillai, G.G.; Bhat, H.R.; Verma, A.; Singh, U.P. Design and discovery of novel monastrol-1,3,5-triazines as potent anti-breast cancer agent via attenuating epidermal growth factor receptor tyrosine kinase. Sci. Rep. 2017, 7, 5851. [CrossRef] [PubMed]

95. Lu, X.; Huang, A.; Xiao, M.; Sun, L.; Mao, J.; Luo, G.; Xiang, H. A new class of 1,3,5-triazine-based selective estrogen receptor degraders (SERDs): Lead optimization, molecular docking and dynamic simulation. Bioorg. Chem. 2020, 97, 1036662. [CrossRef]

96. Junaid, A.; Lim, F.P.L.; Chuah, L.H.; Dolzhenko, A.V. 6, $N^{2}$-Diaryl-1,3,5-triazine-2,4-diamines: Synthesis, antiproliferative activity and 3D-QSAR modeling. RSC Adv. 2020, 10, 12135-12144. [CrossRef]

97. Lakshmithendral, K.; Saravanan, K.; Elancheran, R.; Archana, K.; Manikandan, N.; Arjun, H.A.; Ramanathan, M.; Lokanath, N.K.; Kabilan, S. Design, synthesis and biological evaluation of 2-(phenoxymethyl)-5-phenyl-1,3,4-oxadiazole derivatives as anti-breast cancer agents. Eur. J. Med. Chem. 2019, 168, 1-10. [CrossRef]

98. El-Din, M.M.G.; El-Gamal, M.I.; Abdel-Maksoud, M.S.; Yoo, K.H.; Oh, C.-H. Synthesis and in vitro antiproliferative activity of new 1,3,4-oxadiazole derivatives possessing sulfonamide moiety. Eur. J. Med. Chem. 2015, 90, 45-52. [CrossRef]

99. Dhawan, S.; Kerru, N.; Awolade, P.; Singh-Pillay, A.; Saha, S.T.; Kaur, M.; Singh, P. Synthesis, computational studies and antiproliferative activities of coumarin-tagged 1,3,4-oxadiazole conjugates against MDA-MB-231 and MCF-7 human breast cancer cells. Bioorg. Med. Chem. 2018, 26, 5612-5623. [CrossRef] [PubMed]

100. Tahmasvand, R.; Bayat, P.; Vahdaniparast, S.M.; Dehghani, S.; Kooshafar, Z.; Khaleghi, S.; Almasirad, A.; Salimi, M. Design and synthesis of novel 4-thiazolidinone derivatives with promising anti-breast cancer activity: Synthesis, characterization, in vitro and in vivo results. Bioorg. Chem. 2020, 104, 104276. [CrossRef] [PubMed]

101. Sala, M.; Chimento, A.; Saturnino, C.; Gomez-Monterrey, I.M.; Musella, S.; Milite, C.; Sinicropi, M.S.; Caruso, A.; Sirianni, R.; Tortorella, P.; et al. Synthesis and cytotoxic activity evaluation of 2,3-thiazolidin-4-one derivatives on human breast cancer cell lines. Bioorg. Med. Chem. Lett. 2013, 23, 4990-4995. [CrossRef] [PubMed] 
102. El-Kashef, H.; Badr, G.; El-Maali, N.A.; Sayed, D.; Melnyk, P.; Lebegue, N.; El-Khalek, R.A. Synthesis of a novel series of (Z)-3,5-disubstituted thiazolidine-2,4-diones as promising anti-breast cancer agents. Bioorg. Chem. 2020, 96, 103569. [CrossRef] [PubMed]

103. Wang, G.; Liu, W.; Huang, Y.; Li, Y.; Peng, Z. Design, synthesis and biological evaluation of isoxazole-naphthalene derivatives as anti-tubulin agents. Arab. J. Chem. 2020, 13, 5765-5775. [CrossRef]

104. Wang, G.; Liu, W.; Peng, Z.; Huang, Y.; Gong, Z.; Li, Y. Design, synthesis, molecular modeling, and biological evaluation of pyrazole-naphthalene derivatives as potential anticancer agents on MCF-7 breast cancer cells by inhibiting tubulin polymerization. Bioorg. Chem. 2020, 103, 104141. [CrossRef] [PubMed]

105. Jha, A.; Yadav, Y.; Naidu, A.B.; Rao, V.K.; Kumar, A.; Parmar, V.S.; MacDonald, W.J.; Too, C.K.; Balzarini, J.; Barden, C.J.; et al. Design, synthesis and bioevaluation of novel 6-(4-hydroxypiperidino)naphthalen-2-ol-based potential selective estrogen receptor modulators for breast cancer. Eur. J. Med. Chem. 2015, 92, 103-114. [CrossRef]

106. Reddy, S.T.; Mendonza, J.J.; Makani, V.K.K.; Bhadra, M.P.; Uppuluri, V.M. Synthesis of some novel methyl $\beta$-orsellinate based 3, 5-disubstituted isoxazoles and their anti-proliferative activity: Identification of potent leads active against MCF-7 breast cancer cell. Bioorg. Chem. 2020, 105, 104374. [CrossRef] [PubMed]

107. Dawood, D.H.; Nossier, E.S.; Ali, M.M.; Mahmoud, A.E. Synthesis and molecular docking study of new pyrazole derivatives as potent anti-breast cancer agents targeting VEGFR-2 kinase. Bioorg. Chem. 2020, 101, 103916. [CrossRef]

108. Coskun, D.; Tekin, S.; Sandal, S.; Coskun, M.F. Synthesis, characterization, and anticancer activity of new benzofuran substituted chalcones. J. Chem. 2016, 2016. [CrossRef]

109. Jina, L.P.; Xiea, Q.; Huanga, E.F.; Wanga, L.; Zhanga, B.-Q.; Hub, J.-S.; Wanb, D.C.C.; Jina, Z.; Hua, C. Design, synthesis, and biological activity of a novel series of benzofuran derivatives against oestrogen receptor-dependent breast cancer cell lines. Bioorg. Chem. 2020, 95, 103566. [CrossRef] [PubMed]

110. Eldehna, W.M.; Nocentini, A.; Elsayed, Z.M.; Al-Warhi, T.; Aljaeed, N.; Alotaibi, O.J.; Al-Sanea, M.M.; Abdel-Aziz, H.A.; Supuran, C.T. Benzofuran-based carboxylic acids as carbonic anhydrase inhibitors and antiproliferative agents against breast cancer. ACS Med. Chem. Lett. 2020, 11, 1022-1027. [CrossRef]

111. Shaldam, M.; Eldehna, W.M.; Nocentini, A.; Elsayed, Z.M.; Ibrahim, T.M.; Salem, R.; El-Domany, R.A.; Capasso, C.; Abdel-Aziz, H.A.; Supuran, C.T. Development of novel benzofuran-based SLC-0111 analogs as selective cancer-associated carbonic anhydrase isoform IX inhibitors. Eur. J. Med. Chem. 2021, 216, 113283. [CrossRef]

112. Eldehna, W.M.; Al Rashood, S.T.; Al-Warhi, T.; Eskandrani, R.O.; Alharbi, A.; El Kerdawy, A.M. Novel oxindole/benzofuran hybrids as potential dual CDK2/GSK-3 $\beta$ inhibitors targeting breast cancer: Design, synthesis, biological evaluation, and in silico studies. J. Enzyme Inhib. Med. Chem. 2021, 36, 270-285. [CrossRef]

113. O’Boyle, N.M.; Ana, G.; Kelly, P.M.; Nathwani, S.M.; Noorani, S.; Fayne, D.; Bright, S.A.; Twamley, B.; Zisterer, D.M.; Meegan, M.J. Synthesis and evaluation of antiproliferative microtubule-destabilising combretastatin A-4 piperazine conjugates. Org. Biomol. Chem. 2019, 17, 6184. [CrossRef]

114. Bhat, M.A.; Al-Dhfyan, A.; Khan, A.A.; Al-Harbi, N.; Manogaran, P.S.; Alanazi, A.M.; Fun, H.-K.; AlOmar, M.A. Targeting HER-2 over expressed breast cancer cells with 2-cyclohexyl-N-[(Z)-(substituted phenyl/furan-2-yl/thiophene-2yl)methylidene]hydrazine-carbothioamide. Bioorg. Med. Chem. Lett. 2015, 25, 83-87. [CrossRef] [PubMed]

115. Weldon, D.J.; Saulsbury, M.D.; Goh, J.; Rowland, L.; Campbell, P.; Robinson, L.; Miller, C.; Christian, J.; Amis, L.; Taylor, N.; et al. One-pot synthesis of cinnamylideneacetophenones and their in vitro cytotoxicity in breast cancer cells. Bioorg. Med. Chem. Lett. 2014, 24, 3381-3384. [CrossRef]

116. Varela, C.L.; Amaral, C.; da Silva, E.T.; Lopes, A.; Correiada-Silva, G.; Carvalho, R.A.; Costa, S.C.; Roleira, F.M.; Teixeira, N. Exemestane metabolites: Synthesis, stereochemical elucidation, biochemical activity and antiproliferative effects in a hormonedependent breast cancer cell line. Eur. J. Med. Chem. 2014, 87, 336-345. [CrossRef] [PubMed]

117. Ansari, M.I.; Hussain, M.K.; Arun, A.; Chakravarti, B.; Konwar, R.; Hajela, K. Synthesis of targeted dibenzo [b,f]thiepines and dibenzo[b,f]oxepines as potential leadmolecules with promising anti-breast cancer activity. Eur. J. Med. Chem. 2015, 99, 113-124. [CrossRef]

118. Nikolic, A.R.; Petri, E.T.; Klisuric, O.R.; Celic, A.S.; Jakimov, D.S.; Djurendic, E.A.; Gasi, K.M.P.; Sakac, M.N. Synthesis and anticancer cell potential of steroidal 16,17-seco-16,17a-dinitriles: Identification of a selective inhibitor of hormone-independent breast cancer cells. Bioorg. Med. Chem. 2015, 23, 703-711. [CrossRef] [PubMed]

119. Kaur, G.; Mahajan, M.P.; Pandey, M.K.; Singh, P.; Ramisetti, S.R.; Sharma, A.K. Design, synthesis and evaluation of ospemifene analogs as anti-breast cancer agents. Eur. J. Med. Chem. 2014, 86, 211-218. [CrossRef]

120. Eldehna, W.M.; El Hassab, M.A.; Abo-Ashour, M.F.; Al-Warhi, T.; Elaasser, M.M.; Safwat, N.A.; Suliman, H.; Ahmed, M.F.; Al-Rashood, S.T.; Abdel-Aziz, H.A.; et al. Development of isatin-thiazolo[3,2-a]benzimidazole hybrids as novel CDK2 inhibitors with potent in vitro apoptotic antiproliferative activity: Synthesis, biological and molecular dynamics investigations. Bioorg. Chem. 2021, 110, 104748. [CrossRef]

121. Alkhaldi, A.A.; Al-Sanea, M.M.; Nocentini, A.; Eldehna, W.M.; Elsayed, Z.M.; Bonardi, A.; Abo-Ashour, M.F.; El-Damasy, A.K.; Abdel-Maksoud, M.S.; Al-Warhi, T.; et al. 3-Methylthiazolo[3,2-a]benzimidazole-benzenesulfonamide conjugates as novel carbonic anhydrase inhibitors endowed with anticancer activity: Design, synthesis, biological and molecular modeling studies. Eur. J. Med. Chem. 2020, 207, 112745. [CrossRef] 
122. Lu, C.; Wang, X.; Yang, Y.; Liu, X. Ferrocenyl compounds derived from the reaction of phenylamines with ferrocene carbonyl chloride: Synthesis, characterization and their biological activity. Inorg. Chim. Acta 2016, 447, 121-126. [CrossRef]

123. Tan, Y.L.K.; Pigeon, P.; Top, S.; Labbé, E.; Buriez, O.; Hillard, E.A.; Vessières, A.; Amatore, C.; Leong, W.K.; Jaouen, G. Ferrocenyl catechols: Synthesis, oxidationchemistry and anti-proliferative effects on MDA-MB-231breast cancer cells. Dalton Trans. 2012, 41, 7537-7549. [CrossRef] [PubMed]

124. Zheng, Y.; Wang, C.; Li, C.; Qiao, J.; Zhang, F.; Huang, M.; Ren, W.; Dong, C.; Huang, J.; Zhou, H.B. Discovery ofnovel SERMs with a ferrocenyl entity based on theoxabicyclo[2.2.1] heptene scaffold and evaluation of their antiproliferative effects in breast cancer cells. Org. Biomol. Chem. 2012, 10, 9689-9699. [CrossRef]

125. de Jesús Cázares-Marinero, J.; Top, S.; Jaouen, G. Synthesis and characterization of new ferrocenylcompounds with different alkyl chain lengths andfunctional groups to target breast cancer cells. J. Organomet. Chem. 2014, 751, 610-619. [CrossRef]

126. Wambang, N.; Schifano-Faux, N.; Aillerie, A.; Baldeyrou, B.; Jacquet, C.; Bal-Mahieu, C.; Bousquet, T.; Pellegrini, S.; Ndifon, P.T.; Meignan, S.; et al. Synthesis and biological activity of ferrocenylindeno[1,2-c]isoquinolines as topoisomerase II inhibitors. Bioorg. Med. Chem. 2016, 15, 651-660. [CrossRef]

127. Wu, D.; Guo, L.; Li, S.-J. Synthesis, structural characterization and anti-breast cancer activity evaluation of three new Schiff base metal (II) complexes and their nanoparticles. J. Mol. Struct. 2020, 1199, 126938. [CrossRef]

128. Stojkovic, D.L.; Jevtic, V.V.; Radic, G.P.; Đacic, D.S.; Curcic, M.G.; Markovic, S.D.; Đinovic, V.M.; Petrovic, V.P.; Trifunovic, S.R. Stereospecifc ligands and their complexes. Part XII. Synthesis, characterization and in vitro antiproliferative activity of platinum(IV) complexes with some $\mathrm{O}, \mathrm{O}^{\prime}$-dialkyl esters of $(\mathrm{S}, \mathrm{S})$-ethylenediamineN,N'-di-2-propanoic acid against colon cancer (HCT-116) and breast cancer (MDA-MB-231) cell lines. J. Mol. Struct. 2014, 1062, 21-28.

129. Varela, J.G.; De Chatterjee, A.; Guevara, P.; Ramirez, V.; Metta-Magana, A.J.; Villagran, D.; Varela-Ramirez, A.; Das, S.; Nunez, J.E. Synthesis, characterization, and evaluation of cis-diphenyl pyridineamine platinum(II) complexes as potential anti-breast cancer agents. JBIC J. Biol. Inorg. Chem. 2014, 19, 967-979. [CrossRef] [PubMed]

130. Kutlu, T.; Yıldırım, I.; Karabıyık, H.; Kılınçlı, A.; Tekedereli, İ.; Gök, Y.; Dikmen, M.; Akta, A. Cytotoxic activity and apoptosis induction by a series $\mathrm{Ag}(\mathrm{I})-\mathrm{NHC}$ complexes on human breast cancer cells and non-tumorigenic epithelial cell line. J. Mol. Struct. 2020, 1228, 129462. [CrossRef] 